\title{
The role of the Georgian Apostolic Autocephalous Orthodox Church in conflicts in the South Caucasus
}

Outline of content: The article sheds light on the questions related to the presence of Christians in the Georgian territories and demonstrates the important role played by the Georgian Apostolic Autocephalous Orthodox Church in the history of the Georgian people. As the national identity of the Georgians is closely tied to Christianity and autonomous structures of the Church, which has a profound impact of relations with non-Georgian communities (Georgia has the largest percentage of ethnic minorities in the Southern Caucasus) inhabiting Georgia for centuries, speaking its language, but regarded as "alien" due to their "non-Georgian" religion. The fact that the new authorities provided the Georgian Apostolic Autocephalous Orthodox Church with an exceptional role in the state (after the country regained its independence in 1991) has exacerbated ethnic, religious, and social conflicts in Georgia, which translates into the relations of the country with its neighbours. Such are the questions examined by the author in the presented article. The author reveals how, under the conditions in Georgia resulting from the specific relations between the Church and the State, religion was instrumentalised and used to achieve immediate political aims. Her conclusion is that religion in Georgia inspires nationalist entities and supports nationalism.

Keywords: Georgia, Apostolic Autocephalous Orthodox Church, Catholicos (Patriarch), religious conflicts, ethno-religious conflicts, social conflicts, minorities, religious minorities, sexual minorities, Church-State relations

The $21^{\text {st }}$ century has drawn attention to religion as a factor explaining international relations and mechanisms of the functioning of the world and politics. Until then, the role of religion was ignored in social sciences - the reason being that studies focused mainly on Western countries, where religious influences were the smallest. ${ }^{1}$ It had also been mistakenly believed that with the progress of modernisation (understood as westernisation) religious influences in other parts of the world

1 This was noticed by J. Fox and S. Sandler, Bringing Religion into International Relations, New York, 2004. 
would wane. Meanwhile, one of the consequences of the modernisation processes was a resurgence of religion (as well as reaching towards religious legitimacy). ${ }^{2}$ In a considerable part of the world, democracy is an attack on social systems based on religious principles. Georges Corm rightly points out that the moment religion began losing its transcendental character and started being used for political purposes by power systems leading societies, many believers - including politicians who did not accept such a situation - proclaimed the need to return to the sources, return to the roots. This was creating a situation in which it was easy to confuse religious identity with national identity. The appeal to religion would also become a remedy for deep disenchantment with politics, as well as a remedy for the devaluing system of shaping a modern national identity, rising above ethnicity and religious specificity. ${ }^{3}$ According to some theories, there is an increasingly strong relationship between religion and internal and external conflicts. There is a growing phenomenon of "politicisation of religion" - religion begins to perform integratory functions, as well as mobilising, educational, and ultimately also a political function. ${ }^{4}$

The subject of the following discussion will be the impact of the religious factor on the changes taking place in the Republic of Georgia after 1991. It will be analysed both as a generator of conflict (ethnic, social, international), as well as soothing, or solving, the conflict. As in the subject literature there are quite a lot of studies approaching this issue in a theoretical manner, this text will be a case study. ${ }^{5}$ The author will attempt to trace how different actors of a religious nature in Georgia may be impacting, directly and indirectly, on the internal politics of the state, and to what extent it is relevant for shaping international relations. Of main interest will be tracing the relationship between the stance (support or lack thereof) of the religious authority that is the Catholicos Ilia II towards specific conflicts, and to what extent this becomes a factor leading to the outbreak or the end of a conflict.

For more than sixteen centuries, Georgia has been an orthodox Christian country. ${ }^{6}$ Since the Middle Ages, the Georgian $\mathrm{Church}^{7}$ has been developing

${ }^{2}$ M. Marczewska-Rytko, Religia i polityka w globalizującym się świecie, Lublin, 2010, pp. 80-86.

${ }^{3}$ G. Corm, Religia i polityka w XXI wieku, transl. E. Cylwik, Warszawa, 2007, p. 86.

${ }^{4}$ A. Legucka, Geopolityczne uwarunkowania i konsekwencje konfliktów zbrojnych na obszarze proradzieckim, Warszawa, 2013, p. 108.

5 T. Szyszlak, "Próby teoretycznego ujęcia postradzieckich konfliktów religijnych", in: Religia i polityka na obszarze Europy Wschodniej, Kaukazu i Azji Centralnej, ed. T. Stępniewski, LublinWarszawa, 2013, pp. 49-64; S. Matiunin, "Konflikty religijne na terenie byłego ZSRR", in: Religie $i$ kościoły w społeczeństwach postkomunistycznych, ed. I. Borowik, A. Szyjewski, Kraków, 1993, pp. 204-209; Религия и конфликт, еd. А. Малашенко, С. Филатов, Москва, 2007.

${ }^{6}$ In the eastern part of Georgia, in Iberia, Christianity was recognised as the ruling religion in the year 337, and autocephaly - in 483. In the western part, Lazika, it took place only in 523; D. Zadura, "Chrześcijaństwo i Kościół narodowy w historii Gruzji - od źródeł do okresu sowieckiego”, Pro Georgia. Journal of Kartvelological studies, 19 (2009), pp. 134-136. Cf. also: G. Peradze, 
a particular sense of religious separateness both from the world of Islam and the world of the Orthodox Church - through language, own tradition (also in architecture and church singing) and a number of national and religious myths. ${ }^{8}$ The national identity of Georgians is strongly associated with Christianity and separate ecclesiastical structures. ${ }^{9}$ For many centuries, the Georgian Church has been a strong institution of a national character, which, especially after Georgia lost its statehood, has fulfilled, parallel to religious services, specific political and social functions: cultivating national memory, and guarding national traditions and culture. The long tradition of autocephaly and the differences resulting from autonomous development have created a specific sense of attachment to the Church, which Georgians have expressed by opposing its subordination to the Russian Orthodox Church, or the Russian Empire, or Soviet authorities. ${ }^{10}$

As a result of Russia's policies on Georgian territories (the 1811 liquidation of autocephaly of the Georgian Church and the lack of respect for Georgian traditions), the initial sympathy for Russia based on common religion (for which Georgians did not support the Caucasian highlanders in their struggle against Russians), and a search for an ally in the fight against Turks, were replaced by resentment and hostility. ${ }^{11}$ After the abolition of the Caucasian Governorate in 1882, and tightening the Russification policy towards Georgians - particularly the war on language - the authorities tried to strengthen the Russian ethnic group on Georgian territories. Georgians were settled into areas on the coasts of the Black Sea in the place of displaced Muslims, and ethnic minorities inhabiting Georgian territories - in particular Ossetians - were supported. The Russian Empire put a wedge between Georgian tribes, using differences between the Georgian and Megrelian languages - creating a new alphabet for the Megrelian language, promoting it, and affirming Megrelians in their conviction of being distinct from other Georgian tribes. ${ }^{12}$

\footnotetext{
"Problemy historii początków Kościoła Gruzińskiego", in: id., Dzieła zebrane, vol. 2, ed. Rev. H. Paprocki, Warszawa, 2011, pp. 7-25; R.G. Suny, The Making of Georgian Nation, Bloomington, 1994, pp. 20-41.

7 Its official name is the Georgian Apostolic Autocephalous Orthodox Church. In this work, the author uses the term "the Georgian Church" (qartuli eklesia).

8 The Georgian Church was united in the $12^{\text {th }}$ century, when the Patriarch of Antioch accepted jurisdiction claims of the Catholicos of Mtskheta to the entire Georgian language territory. The result of the unification of Church structures in the east and west of Georgia was receiving the title of the Catholicos-Patriarch of All Georgia by the Mtskheta Patriarchs; Zadura, Chrześcijaństwo i Kościół narodowy, pp. 133, 141.

9 The importance of religion as a factor shaping the development of the Georgian nation was deliberately ignored in Soviet literature and historiography.

${ }^{10}$ D. Zadura, "Naród w tygrysiej skórze. Tożsamość narodowa Gruzinów w dobie 'rewolucji róż", in: Dylematy kaukaskie. Problemy narodowościowe i migracyjne, ed. M. Ząbek, Warszawa, 2010, pp. 286-287.

${ }^{11}$ N. Sabanadze, Globalization and nationalism: the cases of Georgia and the Basque country, Budapest-New York, 2010, http://books.openedition.org/ceup/573, [point 20] (access: 1 July 2015).

12 A. Furier, Droga Gruzji do niepodległości, Poznań, 2009, p. 61.
} 
Georgia is a country where internal ethnographic differences ${ }^{13}$ are highly visible to this day. Most of the differences are due to historical reasons and date back to the times of Georgian tribes (including Kartvelians, Megrelians and Svans), united before our era. The long period of existence of two Georgian countries - Eastern (Iberia) and Western (Colchis), two directions from which Christianity arrived (to the western kingdom from Byzantium, to the eastern one from Syria and Palestine), and the existence of two areas of influence of powerful neighbours (in the western part - Greece, Byzantium, the Ottoman Empire, and in the eastern part - Persia), all this has affected the consolidation of ethnographic differences. ${ }^{14}$ In Georgia, the ethnic mosaic is complemented by religious divisions. Religious heterogeneity within a single ethnic group is the result of a turbulent history. Wars and political events triggered waves of emigration of the settled people and an influx of displaced groups from other areas.

As a result of the historical turmoil, a complicated ethnic and religious situation evolved on Georgian lands. Currently, Georgia is the country with the highest percentage of ethnic minorities in the South Caucasus. More than $80 \%$ of citizens are ethnic Georgians, of which the vast majority (83\%) belong to the Georgian Church. Nearly 10\% of Georgian residents are Muslim, ${ }^{15}$ and about 6\% are followers of the Armenian Apostolic Church. Apart from the Orthodox Church, Islam, and the Armenian Church, the so-called traditional religions of Georgia also include Roman Catholicism (about 35,000 of followers) and Judaism (about 10,000 followers). The number of Yazidis living in Georgia is estimated at 18,000. The Protestant communities are difficult to estimate, but do not exceed $1 \% .{ }^{16}$

In Soviet times, the Georgian Church experienced repressions similar to other churches - first, its assets were taken away, then churches were closed, and the clergy and believers persecuted. ${ }^{17}$ Stalinist repressions were aimed at religions in general, and so other churches fell victim to them as well. The communists' notorious hostility towards religion had not just doctrinal or ideological justification, but also pragmatic. The church was seen in the terms of a quasi-political force, competing with the official, state centre of authority, and its existence successfully

13 Ethnographic group are identified on the basis of separate, objective cultural characteristics, although not always the awareness of separateness. They usually form part of ethnic groups and communities or appear on their overlap. See: Zadura, Naród w tygrysiej skórze, p. 291.

${ }^{14}$ Ibid., pp. 291-292.

15 They are mainly Azeris, residents of Adjara, Chechens, some Abkhazians, Tatars and Avars.

16 G. Rtskhiladze, "Religion and Conflict Potential in Georgia", Central Asia and the Caucasus, 3 (39) (2005), p. 56. The data did not change greatly over the next years, cf. Georgia 2013 International Religious Freedom Report, Department of State USA, www.state.gov/documents/organization/222429.pdf (access: 15 July 2015).

17 For more on this topic see G. Peradze, "Kościół Gruziński pod bolszewizmem", in: id., Dzieła zebrane, pp. 285-288; T.T. Chmielowski, "Kościół Prawosławny w Gruzji w latach zaboru rosyjskiego i władzy sowieckiej (XIX-XX w.)”, Archiwa, Biblioteki i Muzea Kościelne, 70 (1998), pp. 303-313. 
prevented monopolisation and centralisation of power by the communists. ${ }^{18}$ Repressions experienced by the Georgian Church led to the decision of the Holy Synod of the Georgian Church in 1927 that, in order to survive, it needed to cooperate with the new authorities and stay loyal to them. ${ }^{19}$

The Georgian Church began to fully emphasise its cultural role in the history of Georgia during the thaw associated with Gorbachev's perestroika. At this time, standing up for the Georgian Church became a manifestation of national identity. At mass demonstrations, crosses and icons, hated and forbidden by authorities, were used as a symbol. ${ }^{20}$ This extremely strong emphasis on the role of the national Church was a protest against atheistic communism and persecutions, which both the Church and the Georgian nation suffered from the Russian Empire and the Union of Soviet Socialist Republics (USSR). ${ }^{21}$ The actions of the Georgian Church have been in line with the noticeable patterns of the era of political transformations after the fall of communism. A process occurring in most countries which regained their independence is using the occasion by local churches, mainly Orthodox churches, to fill the void left behind by ideological communism, thereby strengthening their presence in the public space, which for decades had been forced out. ${ }^{22}$ They also make demands to the state to recognise them as dominant in a given territory, and to limit the rights of the followers of other religions, which in practice prevents their institutional development. ${ }^{23}$

Georgians saw to it that the most important legal act granted their Church a unique role in the country. The Georgian constitution, adopted by the parliament on 24 August 1995, in the article 14 guarantees all citizens freedom and equality before the law, irrespective of their religion, their national, ethnic and social background, or their beliefs. This is repeated in the article 38, paragraph 1 ("Citizens of Georgia shall be equal in their social, economic, cultural and political lives irrespective of national, ethnic, religious, or language origin"), and the article 19, paragraph 1 specifies these provisions, ensuring everyone has the freedom of speech, opinion, religion or conviction, provided that they do not infringe the

${ }_{18}$ R. Zenderowski, Religia a tożsamość narodowa i nacjonalizm w Europie Środkowo-Wschodniej. Między etnicyzacja religii a sakralizacja etnosu (narodu), Wrocław, 2011, pp. 80-81.

19 Zadura, Chrześcijaństwo i Kościół narodowy, p. 153.

20 The Catholicos e.g. unsuccessfully tried to persuade people to disperse on 9 April 1989, when the armed forces of the Transcaucasian Military District massacred demonstrators gathered in Rustaveli Avenue in Tbilisi; W. Materski, Gruzja, Warszawa, 2010, p. 258.

${ }^{21}$ R. Król-Mazur, "Polityczne aspekty działalności Prawosławnego Autokefalicznego Apostolskiego Kościoła Gruzińskiego po 1991 r.", in: Na wschód od linii Curzona. Księga Jubileuszowa dedykowana profesorowi Mieczysławowi Smoleniowi, ed. R. Król-Mazur, M. Lubina, Kraków, 2014, p. 281; cf. also A. Furier, "Znaczenie relacji między Kościołem a władzami państwowymi dla kształtowania się państwa i narodu gruzińskiego", in: Etniczność a religia, ed. A. Posern-Zieliński, Poznań, 2003, p. 155.

${ }^{22}$ Zenderowski, Religia a tożsamość, pp. 93-94.

${ }^{23}$ Ibid., p. 95. 
rights and freedoms of others. ${ }^{24}$ What is more, paragraph 2 of the aforementioned article prohibits any manifestations of religious hatred, and paragraph 3 contains rules prohibiting any restrictions on the right to religious freedom. ${ }^{25}$ Unfortunately, these provisions remained a dead letter for a long time. ${ }^{26}$

As a result of fierce fighting in the parliament, the Georgian Church was granted a unique role in the country, which was reflected in the article 9, paragraph 1 of the Constitution: "The State shall declare absolute freedom of belief and religion. At the same time, the State shall recognise the outstanding role of the Apostolic Autocephalous Orthodox Church of Georgia in the history of Georgia and its independence from the State". ${ }^{27}$ In this way, Georgia became the second country, next to Armenia, which departed from the principle of separation of church and state..$^{28}$

As the Constitution at the same time guaranteed the freedom of other religions, on 30 March 2001 paragraph 2 was added to article 9, which stated that the relationship between the state and the Georgian Church would be regulated by constitutional agreement. It was signed on 14 October 2002 in the Svetitskhoveli Cathedral in Mtskheta by Ilia II and Eduard Shevardnadze, and then ratified on 22 October by the parliament and the Holy Synod, despite the opposition of Georgian lawyers and professionals from the European Parliament. Its signing was justified mainly by historical reasons - the fact of it being a State religion and its impact on the formation of culture, worldview, and national values. ${ }^{29}$ The agreement consists of 12 articles, preceded by a preamble. ${ }^{30}$ As part of the Constitution, it is superior to other legal acts and provides recognition for the rank of the Georgian Church. It recognises the legal personality of the Georgian Church, its institution, and the inviolability of the Catholicos as Patriarch of All Georgia (article 1 , paragraph $3,4,5)$. It also regulates issues such as holidays, marriage, confession, chaplains, religious education (the Georgian Church has the exclusive right to

24 The Constitution of the Republic of Georgia, Parliament of Georgia, http:// www.parliament.ge/ files/68_1944_951190_CONSTIT_27_12 June pdf (access: 18 November 2014); G. Kuca, M. Grzybowski, System konstytucyjny Gruzji, Warszawa, 2012, p. 25.

25 The Constitution of the Republic of Georgia.

${ }^{26}$ In order to defend and respect human rights, on 15 September 1991 Georgia adopted the Declaration of Human Rights, thus taking on the obligation to respect and defend the right to freedom, imposed by the United Nations Organisation.

27 The Constitution of the Republic of Georgia.

${ }^{28}$ See also T.J. Szyszlak, "Wolność religijna w konstytucjach i ustawach wyznaniowych państw postradzieckich”, Studia z Prawa Wyznaniowego, 10 ( 2007), pp. 242-243.

29 T.J. Szyszlak, "Stosunki państwa z Apostolskim Autokefalicznym Kościołem Prawosławnym we współczesnej Gruzji”, in: Badania wschodnie. Polityka wewnętrzna i międzynarodowa, ed. W. Baluk, Z.J. Winnicki, Wrocław, 2008, p. 80.

30 See "Porozumienie Konstytucyjne między Państwem Gruzińskim i Gruzińskim Apostolskim Autokefalicznym Kościołem Prawosławnym z 14 X 2002”, transl. T. Szyszlak, in: ibid., pp. 361364. 
compose programmes for teaching religion and appointing lecturers ${ }^{31}$ ), property and financing of the Church. ${ }^{32}$ Under the agreement, the Georgian Church has been exempt from paying property taxes, and the person acting as the Catholicos has penal immunity. The Government has also promised to return to the Georgian Church all the lands and movable properties confiscated after the $1917,{ }^{33}$ including those currently in the collections of national museums. It has also been promised that compensation would be paid for years of persecution, and support would be provided for the construction of seminars for clerics who are to serve in the army and prisons. The Georgian Church has been given a decisive voice on the issue of bringing non-Orthodox religious literature to Georgia and building new religious objects - which in practice means subordinating other religious associations to it. ${ }^{34}$

The Georgian Church has also obtained other privileges set down in the constitutional agreement and other legal acts. Difficulties have been introduced to registering religious associations and faith groups as well as issuing the approval of the construction of temples by other religions. The Georgian Church has been given buildings and churches previously owned by Catholics (Gori, Kutaisi, Batumi). It has also received tax breaks, subsidies from the central budget and the possibility of obtaining grants from local government budgets, as well as the right to open its own schools. The Georgian church is making constant efforts to strengthen its position, using constitutional provisions to this end..$^{35}$ In 1999 some proposed to proclaim the Orthodox Church as state religion - this message was promoted by the leader of the movement Our Georgia, Guram Sharadze. ${ }^{36}$ In 2006, 65\% of the Georgian society expressed its support. ${ }^{37}$

${ }^{31}$ In most cases, education in post-Soviet states has been secular in character.

32 Porozumienie Konstytucyjne między Państwem Gruzińskim, pp. 361-364; The Political Landscape of Georgia. Political Parties: Achievements, Challenges and Prospects, ed. G. Nodia, Á. Pinto Scholtbach, Delft, 2006, pp. 69-71; P. Nieczuja-Ostrowski, "Religia w polityce w państwach Kaukazu Południowego", in: Religia i polityka na obszarze Europy Wschodniej, Kaukazu i Azji Centralnej, ed. T. Stępniewski, Lublin-Warszawa, 2013, p. 298; L. Kończak, "Religia i konflikty religijne w niepodległej Gruzji”, in: Konflikty na obszarze byłego ZSRR, ed. P. Adamczewski, Poznań, 2009, pp. 167-168.

33 A. Curanović, "Religie, Kościoły i konflikty międzywyznaniowe w regionie Kaukazu”, in: Wprowadzenie do Studiów Wschodnioeuropejskich, vol. 4: Armenia, Azerbejdżan, Gruzja - przeszłość i teraźniejszość, ed. M. Korzeniowski, D. Tarasiuk, K. Latawiec, Lublin, 2013, p. 201.

34 Porozumienie Konstytucyjne między Państwem Gruzińskim, pp. 361-364; A. Curanović, "Rosyjsko-Kaukaskie sąsiedztwo w kontekście stosunków międzywyznaniowych”, in: Kaukaz w stosunkach międzynarodowych. Przeszłość, teraźniejszość, przyszłość, ed. P. Olszewski, K. Borkowski, Piotrków Trybunalski, 2008, pp. 381-382.

35 Curanović, Rosyjsko-kaukaskie sąsiedztwo, pp. 381-382; Kończak, Religia i konflikty, pp. 167$168,171$.

${ }^{36}$ He was shot in 2007 in a Tbilisi street; Szyszlak, Stosunki państwa, p. 83; Kończak, Religia i konflikty, p. 165.

37 A. Szabaciuk, "Między konfliktem a pokojem. Polityka etniczna i wyznaniowa Gruzji w latach 1991-2012”, Wschodnioznawstwo, 2012, p. 68. 
According to a Win/Gallup International Association report, published at the beginning of 2015, Georgia was in the top ten most religious countries in the world.$^{38}$ In reality, however, Georgians know little about their religion, although they participate in rituals and ceremonies increasingly actively. To a large extent, they are motivated by a need to define their affiliation with a particular community.

When reclaiming their freedom, Georgians combined nationalist slogans with Orthodox faith, and a "real Georgian" meant the one who belonged to the Georgian Church. In ideological sense, Georgians who were Catholics, Muslims or atheists were excluded from the nation. As a result, the Georgian Church was for a long time the only one that could function in Georgia, which was in contrast to its centuries-old tradition. ${ }^{39}$ Followers of religions traditionally rooted in Georgia are not considered to be Georgians. ${ }^{40}$ The escalation of nationalism has been, in a way, a response to colonisation and Russification. The Georgian Church has had to find its feet in the new situation, as after the fall of the USSR sects, until then fought against by Soviet authorities, were also able to function in Georgia. Other churches and religious organisations could also be active. Their appearance was perceived as a sign of globalisation. ${ }^{41}$ The progressive changes that occurred during this period led to the overlap of two extremisms - religious and national. Nationalism pulled the Orthodox Church into its orbit, and the citizens of Georgia could often hear: "You are not Georgian, but Armenian, Polish, Russian, or someone yet different". ${ }^{42}$ A result of such an attitude has been numerous acts of violence (while police and authorities remained passive) committed by radical members of the Georgian Church on representatives of other religious groups (especially Jehovah's Witnesses and Hare Krishnas, Baptists, or Pentecostals). In the years 1998 to 2003 in particular, there were frequent pogroms and raids on their temples, while their literature was destroyed. Orthodox radicals put forward requests to expel "sects", ${ }^{43}$

38 Грузия вошла в десятку самых религиозных стран, Православие. Ru, 14 April 2015, http:// www.pravoslavie.ru/news/78649.htm (access: 15 December 2015).

39 Kończak, Religia i konflikty, p. 164.

40 Rtskhiladze, Religion and Conflict, p. 56.

${ }^{41}$ In conditions of globalisation, through measures of mass communication and great migratory movements it is possible to learn more about other religions, and societies become multi-faith. This confrontation between foreign cultures and religions in some countries - in this case also in Georgia - causes the so-called cultural defence. In the case of Georgia, religion (represented by the Georgian Apostolic Autocephalous Orthodox Church) is permanently inscribed in the history and culture of this nation. On the topic of Churches' attitudes towards globalisation, see an interesting text by J. Mariański, "Globalizacja i Kościoły - sprzymierzeńcy czy konkurenci", in: Religia i religijność w warunkach globalizacji, ed. M. Libiszowska-Żółtkowska, Kraków, 2007, pp. 105-126.

42 "Gruzin nie może być katolikiem", Niedziela, 11 June 2008, www.niedziela.pl/wiad. php?p=200806\&idw=149 (access: 4 November 2013).

43 Proselytism practised in Georgia by a variety of "destructive" sects was mentioned at the meeting with the Armenian minority, in Krakow on 25 March 2013, by the Archbishop Raphaël Minassian, the head of Armenian Catholics in Eastern Europe. 
and restrict religious freedom. ${ }^{44}$ There were incidents of public burning of inconvenient religious literature, as well as destroying and looting the offices of non-governmental organisations involved in the protection of human rights. ${ }^{45}$ At that time there were fierce public debates on foreign cultural and religious influences and the role of the Orthodox Church in the preservation of Georgians' national identity. G. Sharadze accused the US Ambassador to Georgia, Richard Miles, and other members of the international community of supporting "sects", and thus of anti-Georgian activities, claiming that it is a duty of the Georgians to defend themselves against the threat posed by foreign religious groups to their nation and tradition. ${ }^{46}$ At the end of August 2002, the spokesman for the Georgian Church Zurab Tskhovrebadze stated that, together with the Georgian Patriarchate, the whole leadership of the country and the society as a whole should join the fight against sects. He described sects as the "fifth column", which should be disarmed, but not by resorting to violence. ${ }^{47}$ According to the data presented in the International Religious Freedom Report for 2013 published by the US State Department (Bureau of Democracy, Human Rights, and Labour), despite the persecution experienced by "non-traditional religious groups" in Georgia, such as Jehovah's Witnesses, Baptists, Pentecostals, Hare Krishnas, their number continues to grow. ${ }^{48}$

At the start of February 2002, representatives of Georgian Catholics, Jews, Muslims, Lutherans and Baptists issued an open letter to the President of Georgia, E. Shevardnadze, requesting the use of necessary measures against violence on religious grounds. Half a year later, 15 US Members of Congress proposed to the President of Georgia the use of effective measures to this end. ${ }^{49}$

Although in the case of large denominations, such as Roman Catholics, Muslims or followers of the Armenian Apostolic Church, going to church and taking part in a service does not pose difficulties, functioning in social life (school, university, work) is a serious problem. ${ }^{50}$ The situation of ethnic and religious minorities has been appraised negatively by the Council of Europe and its Advisory Committee on the Framework Convention for the Protection of National Minorities. ${ }^{51}$

44 The Political Landscape of Georgia, pp. 71-72; Zadura, Naród w tygrysiej skórze, p. 285.

45 Szyszlak, Stosunki państwa, p. 83.

${ }^{46}$ N. Sabanadze, Globalization and nationalism: the cases of Georgia and the Basque country, Budapest-New York, 2010, http://books.openedition.org/ceup/573 [point 79] (access: 1 July 2015).

${ }^{47}$ Szyszlak, Stosunki państwa, pp. 83-84.

${ }^{48}$ Georgia 2013 International Religious Freedom Report, Department of State USA, www.state.gov/ documents/organization/222429.pdf (access: 15 July 2015).

49 Szyszlak, Stosunki państwa, p. 85.

${ }^{50}$ Gruzin nie może być katolikiem.

51 In 2005, Georgia ratified the Framework Convention for the Protection of National Minorities and began a broad period of cooperation with the OSCE High Commissioner to protect the rights of minorities and to promote their integration into mainstream Georgian society, N. Sabanadze, Globalization and nationalism: the cases of Georgia and the Basque country, Budapest-New York, 2010, http://books.openedition.org/ceup/573 [point 88] (access: 1 July 2015). 
In the critical report from 12 October 2009, the situation of ethnic and religious minorities in the country was deemed as one of its most serious internal issues. Attention was drawn to the growing religious tensions stemming from the fact that the authorities favour the Georgian Church, and other religious organisations are unable to register. ${ }^{52}$

Georgian lawyers fighting for human rights point out that nationalist Christian groups are also hostile towards Jews, which in the future may contribute to an outbreak of further conflicts. ${ }^{53}$ Acts of anti-Semitism are on the rise, such as the incident on 4 December 2013 in Tbilisi, when protests took place against Hanukkah celebrations and the participation of the President Giorgi Margvelashvili, during which cries of "Jew" addressed to the President could be heard. The two major ringleaders were arrested and fined in the amount of 100 lari. A Holy Mass in their intention took place, organised outside the Israeli Embassy by a group of priests of the Georgian Church. While Catholicos himself commented on these events as "unacceptable", at the same time he confirmed the right to freedom of speech. ${ }^{54}$

The situation of atheists in the country is much worse, as they experience persecution at every step. There are cases of non-believer students being beaten up by classmates, to which the school, due to the increasing influence of fundamentalist Christian groups, does not respond. ${ }^{55}$

Religion has played an important role in Georgia in the socialisation of children. ${ }^{56}$ While developing a sense of religious belonging, children begin to perceive others (members of other churches, atheists) as enemies or individuals worse than the members of their own group - Georgians, followers of the Georgian Apostolic Autocephalous Orthodox Church. In the future this could lead to even greater divisions and antagonisms in the Georgian society.

The Georgian Church does not hide its negative attitude towards other faiths in Georgia; it sees them as a threat to the religious identity of the nation. The higher clergy of the Georgian Church has undertaken various initiatives aimed at reducing the influence of other churches. According to some Georgians, "the Orthodox Church has pursued a Soviet policy towards these movements, and has

52 Rada Europy o problemach mniejszości etnicznych i religijnych w Gruzji, Ośrodek Studiów Wschodnich, 12.10.2009, http://www.osw.waw.pl/pl//publikacje/tydzień-na-wschodzie/200910-12/rada-europy-o-problemach-mniejszosci-etnicznych-i-religijnych-w-Gruzji (access: 13 April 2015).

${ }^{53}$ Dyskryminacja ateistów w Gruzji. Wpływy Cerkwi w interesie Rosji, 21 July 2015, http://onet.tv/i/ dowiedzsie/dyskryminacja-ateistow-w-gruzji-wplywy-cerkwi-w-interesie-rosji/3zdzlh (access: 22 July 2015).

${ }^{54}$ Georgia 2013 International Religious Freedom Report, Department of State USA, www.state.gov/ documents/organization/222429.pdf (access: 15 July 2015).

${ }^{55}$ Dyskryminacja ateistów w Gruzji. Wplywy Cerkwi w interesie Rosji, http://onet.tv/i/dowiedzsie/ dyskryminacja-ateistow-w-gruzji-wplywy-cerkwi-w-interesie-rosji/3zdzlh (access: 22 July 2015).

56 M.B. McGuire draws attention to his aspect of generating conflict in the work Religia $w$ kontekście społecznym, transl. S. Burdziej, Kraków, 2012, p. 259. 
become a nationalistic institute. Going to church has become a political act for show. This religiousness boom has been connected to nationalism" ${ }^{57}$

Religious extremists have not even hesitated to condemn the Catholicos for inviting, in 1999, the Pope to Georgia. Although the Catholicos met with John Paul II, he did not allow for religious and theological topics to be breached in the conversation, and the day after the meeting banned his followers from attending a Catholic mass held by the Holy Father in a Tbilisi sports hall. He motivated his decision with canons dating to the first centuries of Christianity, forbidding the faithful from attending services celebrated by heretics, in which the Georgian Church includes Catholics. ${ }^{58}$ The Georgian Church, along with a part of the society (mass protests of students who shouted the messages "we oppose a servile agreement with the Vatican", "Georgia is Orthodox"), in 2003 advocated against the conclusion of an international agreement between Georgia and the Vatican. According to the Catholicos, the agreement would lead to tightening the relations between the Georgian Church and the Vatican, and would invite resentment from other religious denominations in Georgia. ${ }^{59}$ Although the agreement was to apply only to inter-state, rather than religious, issues, the Georgian Church began a vehement campaign against it, and Georgian clerics allegedly claimed in public that the agreement was unacceptable, as it in fact presumed the conversion of Georgia to Catholicism. The President E. Shevardnadze bowed to pressure exerted by the Georgian Church and suspended the signing of the agreement. ${ }^{60}$

Preferential legal treatment and support from the authorities allowed the Georgian Church to rebuild its organisational structures. ${ }^{61}$ When recreating its former jurisdictions, the Georgian Church entered a dispute with other Churches and faiths. Five temples were taken away from the Catholics, of which three were in large cities (Kutaisi, Gori, Batumi), with tombstones being removed and Catholic writings destroyed inside. ${ }^{62}$ Georgia has had a dispute with Azerbaijan about the David Gareja monastic complex, which in 2009 was resolved by handing the control over the object to Georgia, and the land on which the monastery stands to Azerbaijan. ${ }^{63}$ The settlement of the case was only apparent. In the face of rumours spread in Georgia according to which Azeri border guards would not allow Georgian pilgrims and tourists into the grounds of the Udabno monastery within the David

${ }^{57}$ Zadura, Naród w tygrysiej skórze, p. 286.

58 Szef watykańskiej dyplomacji oburzony postawa Gruzji, Katolicka Agencja Informacyjna (KAI) 21 September 2003, http://ekai.pl/wydarzenia/x5651/szef-watykanskiej-dyplomacji-oburzonypostawa-gruzji (access: 25 June 2015).

59 Szyszlak, Stosunki państwa, p. 84.

${ }^{60}$ Szef watykańskiej dyplomacji oburzony postawa Gruzji.

${ }^{61}$ For more on this topic see: Nieczuja-Ostrowski, Religia w polityce, p. 297.

${ }^{62}$ Gruzin nie może być katolikiem.

${ }^{63}$ A. Curanović, "Religie, Kościoły i konflikty międzywyznaniowe w regionie Kaukazu", in: Armenia, Azerbejdżan, Gruzja. Przeszłość i teraźniejszość, ed. M. Korzeniowski, D. Tarasiuk, K. Latawiec, Lublin, 2013, p. 212. 
Gareja complex (since Soviet times the Udabno monastery has been on Azerbaijan territory), in May 2012 the Georgian side began talks concerning its handover. ${ }^{64}$ However, consensus requires concessions from both sides, which is not easy.

Most conflicts emerge between the Georgian Church and the Armenian Apostolic Church. Demands refer to a handover of several churches in the Samtskhe-Javakheti region as well as the control of medieval Armenian monasteries in Hokaret and Hustap, in Kvemo Kartli (Georgia) to Armenians. Various arguments have been used in the dispute, involving historians, art historians, ethnographers, employees of the Georgian Academy of Sciences, and representatives of both Churches. ${ }^{65}$

Mutual relations between Armenians and Georgians are further complicated by the politics of the Georgian Church, which fills monasteries and churches in the Samtskhe-Javakheti region, dominated by Armenians, ${ }^{66}$ with Georgian clergy and nuns. This is a very dangerous policy, taking into account the strong separatist aspirations of the local Armenians. ${ }^{67}$ Georgians received the first serious warning during the Russo-Georgian War. On 19 August 2008, Armenians from the Samtskhe-Javakheti and Kvemo Kartli territories issued a declaration in favour of establishing a federal state in Georgia, where the territories inhabited by Armenians would become sovereign entities. It also demanded that the Armenian language be given the status of the state language ${ }^{68}$ In February 2011 a meeting of the Armenians of Javakheti took place outside the Swiss Embassy in Moscow (representing the interests of Georgia in Russia), in which they called for solving the problem of the status of the Georgian diocese of the Armenian Apostolic Church, returning the taken Armenian temples, monasteries and historical monuments, securing equal rights and freedoms to all faith groups registered in Georgia, and complying with Chapter 19 of the Georgian Constitution. ${ }^{69}$ The foundation of the monumental Sameba temple - "the glory of the Georgian Orthodox Church", built in the traditional Armenian district in Tbilisi on the site of the former Armenian

${ }^{64}$ Грузия ведет переговоры с Азербайджаном о передаче монастьря Удабно входяего в комплекс Давид Гареджи, Православие.Ru, 15 December 2012, http://www.pravoslavie.ru/news/53516. htm; Комплекс Давид Гареджи является клтурным памятником Грузии-Грузинский МИД, Православие.Ru, 16 December 2012, http://www.pravoslavie.ru/news/53559.htm (access: 15 June 2015).

${ }^{65}$ Curanović, Religie, Kościoły, pp. 212-213; Kończak, Religia i konflikty, p. 169.

${ }^{66}$ For more on the history of Armenians in Javakheti see B. Рамишвили, Армяно-Грузинский спор: Джавахети или Джавахк?, http://www.ca-c.org/c-g/2007/journal_rus/c-g-4/02.shtml (access: 1 July 2015); M. Marjanli, Armenians. Russia. The Caucasus, Dubai, 2011, pp. 46-55.

${ }^{67}$ In March 1995, in the regions of Akhalkalaki and Akhaltsikhe Armenians dismantled border posts and spoke out in favour of belonging to Armenia; К.С. Гаджиев, Кавказский узел в геополитических приоритетах России, Москва-Логос, 2010, р. 267.

${ }^{68}$ В населенном армянами Самихе - Джавахети поднят вопрос об автономии в составе Грузии, REGNUM -Информационное агентство, 22 August 2008, http://www.regnum.ru/ news/1043811.html\#ixzz29rSJzn8C (access: 27 August 2015).

69 А. Токарев, Влияние государственности на эволюиию политических режимов Грузии и Украины в 1991-2014 годах, Москва, 2015, р. 215. 
cemetery ${ }^{70}$ was received very unfavourably. Churches which belonged to Armenians have been taken away and converted into Georgian Orthodox churches. In Tbilisi, Armenians demand the return of five of their former temples. This occasion is used to stigmatise the destruction of Armenian cemeteries located by the temples. The issue of temple ownership is currently the most serious allegation on the Armenian side against Georgians. ${ }^{71}$ The situation has been complicated even further by the decision of the Georgian Church from 6 February 2006 to create, under the authority of the Bishop of Dmanisi, a new Tashir-Agarak diocese, which is intended to renew the historical diocese of Kvemo Kartli. The problem lies in the fact that the established diocese includes the southern part of Armenia. The Armenian Apostolic Church emphasises that this decision has no legal basis, as the minimum number of the Georgian Church followers (one thousand) is not reached in this region. Moreover, the Georgian Church has requested the Armenian Apostolic Church to return six Georgian monasteries located in the historical district of Kvemo Kartli. In response, on 22 August 2007 one of the members of the Armenian Parliament proposed to create a separate diocese of the Armenian Apostolic Church in the town of Javakheti in southern Georgia, where Armenians represent $91-97 \%$ of the population. ${ }^{72}$ In 2011, The Armenian Church obtained a legal status in Georgia, while the Georgian Church has not yet been granted the same position in Armenia. The Georgian Church has laid claim to four monasteries in the Lori region, Akhtala, Kobayr, Hnevank and Huchap, as well as the monastery of Kirants, located in the Tavush region. The Armenian Church does not agree to it, giving two arguments as primary reasons - the historical Georgian monasteries active in the $11^{\text {th }}-12^{\text {th }}$ centuries were subject to the Armenian Apostolic Church and therefore this is how it should remain, and according to the official data ${ }^{73}$ there are only 600 ethnic Georgians living in Armenia, which also speaks for keeping the current state. ${ }^{74}$ On the Javakheti territory, in several small towns and villages around Akhalkalaki and Akhaltsikhe there are also Armenians Catholics, colloquially called "Franks". ${ }^{75}$ They constitute a separate group in Georgia and are subject to the Ordinariate for Catholics of Armenian Rite in Eastern Europe, created in 1991 and since 2011 headed by Archbishop Raphäl Minassian.

70 Kończak, Religia i konflikty, p. 170.

${ }^{71}$ I. Komoszyńska, "Niektóre aspekty współczesnych antagonizmów gruzińsko-ormiańskich", in: Dylematy kaukaskie. Problemy narodowościowe i migracyjne, ed. M. Ząbek, Warszawa, 2010, p. 315; D. Zadura, Ormiańskie świątynie w Tbilisi, http://www.kaukaz.net/cgibin/blosxom.cgi/ polish/gruzja/gruzja_ormianskie_koscioly (access: 14 June 2015).

${ }^{72}$ Curanović, Rosyjsko-kaukaskie sąsiedztwo, p. 385.

73 Data for 2011.

${ }^{74}$ G. Abramian, Армения: Имущественные споры способствуют эскалации напряженности между иерквями Армении и Грузии, 11 August 2011, Eurasianet.org http://russian.eurasianet. org/node/58814 (access: 20 June 2015).

${ }^{75}$ Separate studies are being carried out regarding this group, e.g. in 2012 the project of the Visegrad Foundation Franks - Armenian Catholics in Georgia. 
In Adjara, following the end of the rule of Aslan Abashidze, the Georgian Church began a policy of emphasising the region's Christian heritage. Adjara TV, controlled by the autonomy's authorities, often broadcasts religious programmes prepared jointly with the patriarchate. However, there are no broadcasts addressed to Adjaran Muslims, ${ }^{76}$ who account for about $48 \%$ of the region's population. Increasingly, many young Adjarans decide to convert to the Orthodox faith in order to become fully-fledged Georgians (e.g. to find work). This has definitely been influenced by representing the Muslim religion as an enemy which for millennia has been trying to destroy the Georgian nation. The fight against Islam is portrayed as a "war of civilisations". ${ }^{77}$ The Georgian Church spends millions in public money on erecting churches and seminaries in Adjaran towns, and the local Orthodox clergy encourages the faithful to persuade their Muslim neighbours to change their religion. ${ }^{78}$

The Georgian Church constantly opposes strengthening the position of Muslims in Georgia. The talks of 27 March 2013 between the head of Turkish diplomacy Ahmet Davutoğlu and Prime Minister Bidzina Ivanishvili, President of the Parliament David Usupashvili, Minister of Foreign Affairs Maia Panjikidze, Minister for Reintegration Paata Zakareishvili, and Catholicos Ilia II addressed the issue of repatriating Meskhetians and constructing a new mosque in Batumi. The latter case was met with numerous reservations from ecclesiastical authorities; nevertheless the Prime Minister announced his support. ${ }^{79}$

The Catholicos did not give his consent to the handover of religious buildings taken from the Armenian Apostolic Church in the Samtskhe-Javakheti region, inhabited mostly by Armenians, or to the construction of mosques for Muslims living in Adjara, which resulted in a shift of the religious disputes to the interstate level. This made it difficult for state authorities to pursue its foreign policies, especially as the Georgian Church has come forward with criticism of their actions. At the end of 2011, Ilia II sent a letter to the Turkish Prime Minister, asking for the return of several churches in north-eastern Turkey, ${ }^{80}$ deeming it an injustice that while mosques are being rebuilt in Georgia, Georgian churches in Turkey are left

${ }^{76}$ More details on Muslims in Adjara in the work of Ruslan Baramidze, "Islam in Adjara - Comparative Analysis of Two Communities in Adjara", in: Changing identities: Armenia, Azerbaijan, Georgia. Collection of Selected Works, ed. V. Voronkov, Tbilisi, 2011, pp. 96-125.

77 Р. Силантьев, “Религиозный фактор во внешнеполитических конфликтах на Кавказе”, in: Религия и конфликт, ed. А. Малашенко, С. Филатов, Москва, 2007, pp. 131-132; Kończak, Religia i konflikty, pp. 170-171; Curanović, Rosyjsko-kaukaskie sąsiedztwo, p. 384.

${ }_{78}$ М. Корсо, Грузия: Растёт дискриминация в отномении мусульман?, 7 September 2013, Eurasianet.org http://russian.eurasianet.org/node/60279 (access: 20 June 2015).

79 W. Wojtasiewicz, "Wybory za pasem”, Nowa Europa Wschodnia (hereafter: NEW), 4 April 2013, www.new.org.pl/2013-04-04,wybory_za_pasem.html (access: 5 June 2015).

${ }^{80}$ One of the features of Georgian monasticism is a centuries-old tradition in which monks travel across the border and establish monasteries in different locations, while at the same time they care for the preservation of their national character, J.M. Laboa, "Monastycyzm gruziński", 
in disrepair. Meanwhile, Georgian authorities, without waiting for a response to Catholicos, during his absence from the country expressed willingness to rebuild mosques in Georgia in exchange for restoring Orthodox churches in Turkey. In response to an initial agreement in which the governments of Georgia and Turkey discussed issues of mutual protection of religious objects, ${ }^{81}$ on 9 February 2012 the Patriarchate of Georgia published its position, in which it accused Turkish authorities of conducting separate negotiations, and stressed that this is how conflicts between Muslims and Christians are provoked. A political warning for authorities was the so-called warning mass, organised in Batumi - a protest of Orthodox believers against the Georgian-Turkish agreement. ${ }^{82}$ However, the new government of Bidzina Ivanishvili decided to continue talks with Turkey about the protection of Muslim rights on Georgian territories. First talks regarding the construction of a new mosque in Batumi were opened by B. Ivanishvili during his trip to Turkey in February 2013, and then continued by the Turkish Foreign Minister Ahmet Davutoğlu, who arrived in Georgia a month later. The topic of restoring Georgian sacral buildings in the north-east of Turkey was also put forward, as was the complicated issue of repatriating Meskhetians. ${ }^{83}$ In August 2014, Catholicos also began talks with Turkish authorities about obtaining legal status for the Georgian Church in Turkey, and the possibility of resuming activities in historical temples located in Turkey. ${ }^{84}$

After parliamentary elections in 2012, when the voice of conservative-nationalist groups became stronger, the temperature of conservative-nationalist moods increased as well. They manifested through riots which erupted on 26 August 2013 in the south of the country in the village of Khela, inhabited by both Orthodox and Muslim Georgians, following the dismantling of the minaret of the Khela mosque by the local authorities. The reason for this was supposedly unlicensed construction

in: Mnisi Wschodu i Zachodu. Historia monastycyzmu chrześcijańskiego, ed. J. M. Laboa, Warszawa, 2009, p. 166.

81 These issues are also regulated by the constitutional agreement - article 10 contains the following provision: "The State shall take responsibility to negotiate with other states on protection, care and management of all Georgian orthodox churches, monasteries and remains thereof, other ecclesiastical buildings, and ecclesiastical items being on their territories", as well as their conservation and management, Constitutional Agreement between State of Georgia, p. 363. On 17 July 2014, an agreement was signed between the state and the Georgian Church regarding joint protection of Georgia's cultural heritage, Государство и Церковь в Грузии будут вместе сохранять культурное наследие, Образованне и Православие, 20 July 2014, http://www. orthedu.ru/hppc/news-hppc/10797-gosudarstvo-i-cerkov-v-gruzii-budut-vmeste-sohranyat.html (access: 20 December 2015).

${ }^{82}$ Król-Mazur, Polityczne aspekty, p. 290.

${ }^{83}$ W. Wojtasiewicz, "Polityka zagraniczna Republiki Gruzji pod rządami premiera Bidziny Iwaniszwilego - kontynuacja czy zmiana?", in: Prawo i polityka na wschód od Europy, ed. J. Marszałek-Kawa, P. Wawrzyński, Toruń, 2014, pp. 142-143.

${ }^{84}$ Patriarch Ilia II asking Turkish authorities to resume services at Georgian churches, Tbilisi, 13 September 2014, http://www.pravoslavie.ru/english/73691.htm (access: 20 June 2015). 
and irregularities when bringing the minaret from Turkey. The government did not respond (although the Union of Georgian Muslims appealed to the Prime Minister Ivanishvili, asking him to intervene), and the tension was diffused as a result of mediation between Muslim communities and Ilia II. ${ }^{85}$ Catholicos stated that the forces which caused the confrontation between Christians and Muslims were aiming to discredit the Church and the state. ${ }^{86}$ However, acts against Muslims continue. In the town of Kobuleti in Adjara, Georgians protested against the construction of a Muslim school by hanging a pig's head on its front door. ${ }^{87}$

The Georgian Prime Minister B. Ivanishvili, trying to dispel concerns about discrimination against ethnic and religious minorities in Georgia, has repeatedly emphasised that Georgia is a tolerant country, and on 2 September 2013 assured representatives of the Muslim community in the presence of the diplomatic corps that "religious tolerance is not only our tradition, but also one of the basic principles of the Constitution of Georgia" ${ }^{88}$ However, the reality is different, and the Georgian Church plays a big part in shaping it.

The overall situation is becoming increasingly dangerous, according to George Sanikidze, the Director of the Institute of Oriental Studies at the Ilia State University in Tbilisi, Muslims in Georgia also are experiencing a religious revival. ${ }^{89}$

According to a report drawn up in 2014 by the Human Right Watch organisation, Muslims in Georgia are still subject to attacks from the Orthodox population. In regions where this group accounts for a considerable percentage of the population, they are not allowed to pray in homes converted to mosques. Various incidents occur, such as the one from April 2014, when in one of the villages in the region of Adjara three drunk police officers stopped cars, searched travellers, called them Tatars and demanded they show the crosses around their necks. ${ }^{90}$ As social conflicts are manifesting more frequently in Georgia, frictions between the Christian and Muslim population in this country are also on the rise. ${ }^{91}$ Like the government, the Georgian Church also does not want the repatriation of

${ }^{85}$ M. Matusiak, "Wzrost nastrojów konserwatywno-nacjonalistycznych?", Ośrodek Studiów Wschodnich, 4 September 2013, http://www.osw.waw.pl/publikacje/analizy/2013_09_04/gruzja-wzrost-nastrojow-konserwatywno-nacjonalistycznych (access: 4 June 2015).

${ }^{86}$ K. Kakachia, "Is Georgia's Orthodox Church an Obstacle to European Values?", PONARS Eurasia Policy Memo, no. 322, June 2014, p. 3, http://www.ponarseurasia.com/sites/default/files/ policy-memos-pdf/Pepm_332_Kakachia\%20_June\%202014.pdf (access: 20 December 2015).

87 Patriarch Ilia II asking Turkish authorities to resume services at Georgian churches, Tbilisi, 13 September 2014, http://www.pravoslavie.ru/english/73691.htm (access: 20 June 2015).

${ }_{88}$ М. Корсо, Грузия: Растёт дискриминация в отномении мусульман?, 7 September 2013, Eurasianet.org http://russian.eurasianet.org/node/60279 (access: 20 June 2015).

89 Ibid.

90 Human Rights World Report 2014: Georgia, http://www.hrw.org/world-report/2014/country-chapters/georgia (access: 10 December 2015).

${ }^{91}$ M. Falkowski, "Gruzja: kryzys polityczny i rosyjskie zagrożenie", Analizy Ośrodka Studiów Wschodnich, http://www.osw.waw.pl/pl/publikacje/analizy/2014-11-19/gruzja-kryzys-polityczny-i-rosyjskie-zagrozenie (access: 10 December 2015). 
Meskhetian Turks on Samtskhe-Javakheti territories (the former does not want conflict with the Armenians who live there, and who have been settled there by the Russians in the place of Meskhetian Turks from mid-19 ${ }^{\text {th }}$ century, and the latter does not want any more Muslims in the country). Georgians have a negative attitude towards Meskhetian Turks and the government uses it, piling up obstacles for obtaining a repatriate status. ${ }^{92}$ Although in 2012 Georgia took on the responsibility of repatriating thousands of Meskhetians to Georgia, ${ }^{93}$ their situation did not change greatly. It is a priority for Georgia to ensure stability in Samtskhe-Javakheti region, as the Baku-Tbilisi-Ceyhan crude oil pipeline and the Baku-Tbilisi-Erzurum gas pipeline run through this area.

Information about discrimination against Muslims in Georgia raises concerns in neighbouring Muslim countries. In August 2013, the Catholicos received delegations of Iranian clergy, led by Ayatollah Shahritsan. The aim of the visit was to examine the situation of Muslims in the Caucasus and their relations with Christians. Using the opportunity, Ilia II appealed to Shahritsan not to enforce punishments on Georgians living in Iran for centuries for converting to Orthodox faith and returning to the religion of their ancestors. ${ }^{94}$

Another problem has been the appointment of a joint committee, which is to take care of the most sensitive issues between Catholics and the Orthodox (e.g. the issue of churches that have been taken away, or recognising Catholic baptisms). Catholic signs and symbols are fought against - there have been cases where children who made the sign of the cross in the Catholic manner in school were hit across their palms. The Georgian Church has been very reluctant towards the activities of Caritas in Georgia run by the Catholic Church, because, in the words of Ilia II, "we are afraid of you, you are a large, rich, and well-organised Church, and we are a tiny one, recovering from the damages of communism. You are a threat to us" ${ }^{95}$ Caritas is the only institution which helps hundreds of thousands of refugees, e.g. from South Ossetia, providing them with a modest daily meal. It works in difficult conditions, without funds, as the topic of refugees is undesirable in the media, since it gives the government a bad image. ${ }^{96}$

92 T. Trier, G. Tarkhan-Mouravi, F. Kilimnik, Meskhetian: Homeward Bound..., Tbilisi, 2011, pp. 42-47, 101; V. Modebadze, "Historical Background of Meskhetian Turks' Problem and Major Obstacles to the Repatriation Process", IBSU Scientific Journal, 3 (2009), no. 1, pp. 124-126.

${ }_{93}$ In 1999, the Georgian government committed itself to the repatriation and reintegration of Meskhetians within twelve years (it was a condition for Georgia's membership in the Council of Europe). Cf. T. Pataraia, "Rozwój polityki migracyjnej w Gruzji”, in: Polityka migracyjna Gruzji: wnioski z polskich doświadczeń, ed. P. Kaźmierkiewicz, T. Pataraia, Warszawa, 2011, p. 117.

94 Илия II попросил Иран не наказывать грузин, возвращающихся в Христианство, 21 August 2013, Образование и Православие, http://www.orthedu.ru/news/7731-iliya-ii-poprosil-iranne-nakazyvat-gruzin-vozvrashhayushhixsya-v-xristianstvo.html (access: 25 June 2015).

${ }_{95}$ Gruzin nie może być katolikiem.

96 A. Dzieduszycka-Manikowska, Dramat kościoła na Kaukazie, PCh24.pl, 4 August 2013, http:// www.pch24.pl/Mobile/Informacje/informacja/id/16759 (access: 12 August 2015). 
The Georgian Church, accused of religious chauvinism, has stood firmly behind maintaining its privileged position despite interventions from international organisations and admonitions from the Council of Europe. ${ }^{97}$ The religious extremism guided by the Church was initially tolerated by the authorities. The situation partly changed after Mikheil Saakashvili rose to power. A fight with religious extremism had already started in the time of the Revolution of Roses, in the hope of winning over the Georgian intelligentsia. The authorities organised a propaganda and information campaign under the slogan "We celebrate Georgian diversity", 98 which was supposed to remind the residents of Georgia of the traditional ethnic and religious tolerance in the country. ${ }^{99}$ The questions of religious freedom, inability to register religious groups and the spread of hate speech by Christian organisations and groups in Georgia in relation to people of different sexual orientation were repeatedly raised by successive ombudsmen in this country. ${ }^{100}$ However, their actions could not change a great deal, as the parliament often only received their reports without passing relevant acts. ${ }^{101}$

Due to Georgia's aspirations for accession to the European Union, its authorities were forced to take steps and decisions at odds with the position and activities of the Georgian Church. The government of M. Saakashvili took actions aimed to stop the activities of people explicitly committing violence against religious minorities - for example, the previously excommunicated by the Georgian Patriarchate fanatical priest Basil Mkalavishvili. ${ }^{102}$ Importantly, in a study conducted in 2003 the activities of Mkalavishvili were seen as "positive" by 45.2 per cent of respondents. ${ }^{103}$

The position of the Georgian Church wavered on 6 July 2011, when a law changing the status of religious minorities in Georgia entered into force - until then,

97 In April 2011, The Parliamentary Assembly of the Council of Europe expressed concern in its resolution about the legal situation of minorities, stressing "the lack of adequate legal status and legal protection for groups and faiths other than GOC [Georgian Orthodox Church]"; Rada Europy chwali Gruzję. Cerkiew protestuje, http://www.kaukaz.info/rada-europy-chwali-gruzje-cerkiew-protestuje.html (access: 29 June 2014).

98 Tbilisi is compared to Jerusalem - it is a meeting point of different cultures, nations and religions. Within the city you can find a Muslim mosque, a Jewish synagogue, an Armenian church, a Catholic Church - called a Polish Church, a Russian Orthodox Church, Lutheran and Baptist Church. It is a home to more than 90 nations and ethnic groups; D. Parzymies, Życie codzienne $w$ Tbilisi 1999-2003, Warszawa, 2004, pp. 37-44, 93-119.

99 Kończak, Religia i konflikty, p. 169.

100 M. Wróblewski, "Partnerstwo na rzecz praw człowieka. Współpraca z Ombudsmanem Gruzji w ramach programu ombudsmanów państw Partnerstwa Wschodniego UE”, in: Gruzja między Wschodem a Zachodem, ed. K. Masiuk et al., Kraków-Warszawa, 2012, p. 108.

${ }^{101}$ In 2007, the parliament rejected the official opportunity to have Sozar Subari present the annual report; L. Leszczenko, Instytucja ombudsmana w państwach proradzieckich. Geneza - status prawny - rozwój, Warszawa, 2011, p. 127.

102 A. Szabaciuk, "Między konfliktem a pokojem. Polityka etniczna i wyznaniowa Gruzji w latach 1991-2012", Wschodnioznawstwo, 2012, pp. 68-69.

103 The Political Landscape of Georgia, p. 72. 
they had been considered non-commercial entities of private law. The first attempts to level the legal status of the Georgian Church and other religious communities were made in December 2005, however some members of the Georgian parliament thwarted them by not taking part in the vote. ${ }^{104}$ The act of 2011 enabled the Armenian Apostolic Church, the Roman Catholic Church, the Evangelical Baptist Church, as well as Muslim and Jewish groups to register as public law entities. These changes were very strongly criticised by the Patriarchate, which even decided to take its followers to the streets. Several thousand people protested against the new legal regulation outside the parliament, led by Orthodox priests. Protest marches were held on 9, 10 and 11 July. Catholicos Ilia II blessed the crowd of protesters, and in the first issued statement stated that the passed law threatened the Georgian Church's special position, and that giving other religions in Georgia legal status should take place once the Georgian Church has received it in other countries (especially Armenia). He also addressed the government in an angry statement, saying that in accepting such a law it humiliated the Georgian Church. ${ }^{105}$ He stated that "this law is important, but also very dangerous, so the legislators should think over what consequences it may have within ten or a hundred years...". 106 The Christian-Democratic Movement began collecting signatures to officially recognise Orthodox Christianity as the state religion. ${ }^{107}$

From the perspective of the ruling camp, the new regulation was likely to improve relations with national minorities, in particular the Armenians residing in dense clusters in the south of the country, poorly integrated with the rest of the country, and constantly accused of separatism. The Georgian Church "led" the mass protests against the law, fearing property claims from the Armenian Church (before 1917, there were between 457 and 600 Armenian temples and monasteries on the territory of Georgia, according to various sources). This is also confirmed by the behaviour of the enraged Georgian believers who on 10 July 2011 attacked several Armenians on the Ketevan Tsamebuli square in Tbilisi and beat them severely. Arnold Stepanian, the head of the Armenian Community of Tbilisi declared that the fuss around the act of 6 July contributed to increased hostility towards Armenians, and that Armenophobia was awakening in Georgia. The authoritative bishop Zenon of Dmanisi, in his speech broadcast by the Maestro radio station on 7 July, pointed to the Armenian Apostolic Church and Armenian

${ }^{104}$ Curanović, Rosyjsko-kaukaskie sąsiedztwo, p. 383.

105 W. Wojtasiewicz, "'Wojna religijna' i afera szpiegowska w Gruzji”, NEW, 18 July 2011, www. new.org.pl/2011-07-18,wojna_religijna_i_afera_szpiegowska_w_gruzji.html (access: 20 July 2014); В. Мальцев, Илия II: “Не унижайте Церковь!” Маситабные протесты православных верующих заставили власти Грузии свернуть с европейского пути, http://www.religare. ru/2_87652.html (access: 26 June 2015).

106 Cerkiew protestuje przeciwko nowemu prawu, http://www.kaukaz.info/cerkiew-protestuje-przeciwko-nowemu-prawu.html (access: 29 June 2014).

107 Мальцев, Илия II. 
authorities as those mainly responsible for passing the above mentioned law by the Georgian parliament. ${ }^{108}$

On 12 July 2011, the Georgian parliament introduced amendments to the already approved law. Politicians of the ruling party reassured the Patriarchate, through the words of Nugzar Tsiklauri, that the Georgian Church would retain a special status guaranteeing it certain fiscal privileges. ${ }^{109}$ And so in the budget for 201425 million lari (approximately 14.4 million dollars) was allocated to subsidies for the Georgian Church. ${ }^{110}$

The Catholicos vehemently opposed the ratification by the Georgian Parliament of the European Charter for Regional or Minority Languages, which guarantees national minorities the right to use one's own language. Georgia committed itself to ratifying it already in 1999. In a statement the Patriarchate said that this document would contribute to the development of separatist tendencies in Georgia, and would reduce the chances of restoring Georgia's territorial integrity. ${ }^{111}$

The Georgian Church also represents a radical position in terms of granting equal rights to sexual minorities, as in the case of the bloody events of 17 May 2013. Orthodox clergy took active part in the violent mass protests organised in Tbilisi against the demonstration of gay rights defenders. ${ }^{112}$ While the events were taking place, the police remained utterly passive. ${ }^{113}$ The Patriarchate of Georgia plays a considerable role in strengthening the homophobic attitudes of a huge part of the Georgian society. ${ }^{114}$ According to research carried out in 2013 by the Caucasus Resource Research Centre, a significant number of Georgians is willing to respect religious minorities, but will never accept sexual minorities, as

108 Ibid.

109 Ibid.; Г. Двали, “Грузия отделилась от церкви”, Коммерсанть, 7 July 2011; Ormianie w Gru$z j i$, http://www.fundacjaormiańska.pl/ormianie-w-gruzji/ (access: 20 July 2015); Gruzińska Cerkiew krytykuje nowe przepisy, http://wiadomosci.wp.pl/kat,1356,title,Gruzinska-Cerkiewkrytykuje-nowe-przepisy,wid,13573623,wiadomosc.html?ticaid=112548 (access: 20 July 2015).

110 Грузия профинансирует Грузинскую Православную Церковь в размере 25 миллионов тари, Православие.Ru, 8 October 2013, http://www.pravoslavie.ru/news/64750.htm (access: 16 December 2015).

111 M. Tauber, Geopolityka, sytuacja wewnętrzna w Gruzji, a stanowisko Gruzińskiej Cerkwi Prawosławnej, 22 April 2013, www.forum-ekonomiczne.pl/article/geopolityka-sytuacja-wewnętrznaw-gruzji-a-stanowisko-gruzinskiej-cerkwi-prawoslawnej/\# (access: 12 January 2015).

112 Król-Mazur, Polityczne aspekty, p. 293.

113 In Georgia, human rights protection is the domain of i.a. one of the structural links of the Ministry of Internal Affairs - the Patrol Police, see M. Marsagiszwili, "Działalność Departamentu Policji Patrolowej Gruzji. Prawa Człowieka”, in: Polsko-gruzińska wymiana doświadczeń $w$ zakresie podejmowania czynności służbowych przez funkcjonariuszy policji $w$ aspekcie praw i wolności człowieka, ed. I. Nowicka, T. Mosio, Szczytno, 2008, pp. 31-34.

114 Human Rights World Report 2014: Georgia, http://www.hrw.org/world-report/2014/country-chapters/georgia (access: 10 December 2015); The Georgian Authorities should not water down the country's first anti-discrimination bill, Amnesty International Public Statement, 24 April 2014, https://www.amnesty.org/en/documents/eur56/001/2014/en/ (access: 20 December 2015). 
they attack their national dignity and offend Christian values. ${ }^{115}$ By radicalising the sentiments of the Georgian society, the Georgian Church has contributed to the rise of radical religious groups - such as The Orthodox Union or Christian Parents, which played a decisive role in the 2012 clashes. ${ }^{116}$ In April 2014, the Georgian Church strongly expressed its opposition to the government's bill to eliminate all forms of discrimination, opposing the provision for legal protection against discrimination on grounds of sexual orientation and gender identity. ${ }^{117}$ In the last years of the government of M. Saakashvili and his United National Movement in particular, the Georgian Church very clearly showed a critical attitude to its pro-Western policies (accepting the standards for the protection of different minorities, including sexual minorities), perceiving them as dangerous to tradition, and claiming that the West is a greater threat to Georgia than Russia. This conviction is present among a large part of the Georgian clergy to this day. Ilia II has often (for example in 2014 New Year's wishes) urged the European Union to take into account the aspirations of Georgia to maintain the country's traditional values and not to impose "same-sex marriages or same-sex family ideals, alien to the Georgian nation". ${ }^{118}$ The anti-Western attitude of the Georgian Church might strengthen in the future, as the European Union and the United States of America provide all sorts of support also to religious minorities, including granting funds for this purpose. ${ }^{119}$

The Georgian Church has also criticised emigration of its followers, who are leaving their native country in increasing numbers, and is also reluctant towards the influx of immigrants to Georgia. The Catholicos speaks out against the sale of land to foreigners - in his view, this poses a threat to the existence of the Georgian state. Ilia II calls on the country's authorities to suspend the process of selling Georgian land to citizens of foreign countries in order to attract foreign capital to Georgia. He stresses that Georgian land should not be sold to foreigners, and that Georgians should not support foreign employees. ${ }^{120}$ We should also bear in mind that Georgia is a shelter for Chechen refugees (where $0.7 \%$ of its immigrants come from), ${ }^{121}$ who, being Muslims, are not welcomed by the Georgian

\footnotetext{
115 A. Chanadiri, Gruzini. Zagubieni Europejczycy, 14 December 2013, http://zw.lt/opinie/gruzinizagubieni-europejczyzy/ (access: 9 July 2015).

116 Kakachia, Is Georgia's Orthodox Church, p. 3.

117 Ibid., p. 5.

118 Król-Mazur, Polityczne aspekty, p. 294.

119 The US Embassy gives grants to local non-governmental organisations to support religious and legal aid for religious minorities, Georgia 2013 International Religious Freedom Report, Department of State USA, 28 July 2014, p. 11, www.state.gov/documents/organization/222429.pdf (access: 15 July 2015).

120 Патриархи Грузии: Продажа земли иностраицам ставит под удар сущетвование государста, Православие.Ru, 14 July 2014, http://www.pravoslavie.ru/news/71975.htm (access: 16 December 2015).

121 Pataraia, Rozwój polityki migracyjnej, p. 114.
} 
Church. Their presence is also a reason for grievances on the part of the Russian Federation.

The increase of social conflicts in Georgia has been fuelled by the Georgian Church's involvement in shaping historical policy - it actively participates in the creation of school curricula (state schools teach history of religion ${ }^{122}$ ), in an attempt to control the work of research centres, ${ }^{123}$ public television and radio. It stands up for television stations broadcasting content in line with the Church's teachings. ${ }^{124}$ The Catholicate also has its own media - the newspaper Grapevine Cross and the radio station Iveria. ${ }^{125}$ Ilia II is a supporter of introducing censorship, which he expressed at the presentation of a book by Erekle Deisadze, Saidumlo Siroba, which caused a scandal in Georgia due to its provocative and offensive content. The Patriarch deemed this publication a manifestation of the battle against the Church and traditional Georgian values, and decorated one of the clerical leaders of a religious organisation who actively participated in the fight which took place during a televised debate about the book. ${ }^{126}$

The constitutional agreement is proof that politicians have noticed the importance of religious issues. Georgian politicians very often refer to religious signs, combining them with national symbols. The importance of the national Church is even clearer to the successive political leaders, beginning with Eduard Shevardnadze. The Prime Minister of Georgia Irakli Garibashvili publicly proclaims that the entire history of Georgia is based on Christian faith. He emphasises the role of the Georgian Church and expresses gratitude to the Catholicos for his work to unify and strengthen the country. ${ }^{127}$

The trust Georgians place in the head of their Church has not changed for many years. He continues to top popularity rankings - in April 2014 he received support of $96 \% .{ }^{128}$ Unfortunately, with age he begins to lose some control over the happenings within the Church - ultraconservative clergy is gaining more and more power. As some Georgian clerics admit, the growth of radical tendencies in the Orthodox Church in Georgia is boosted to a large extent by the lack of competence in the clergy - over the last forty years, the number of priests has increased

122 Król-Mazur, Polityczne aspekty, p. 296.

${ }^{123}$ The Catholicos even intended to build a hotel by the Church of the Holy Trinity, in which he could hold several-day meetings with Georgian intellectuals; ibid.

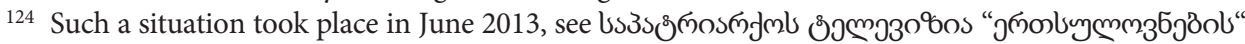

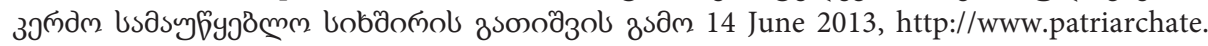
ge/?action=news_show\&mode=news\&id=765 (accessed 4 June 2015).

125 Król-Mazur, Polityczne aspekty, p. 296.

126 D. Zadura, Liberalna demokracja i prawosławny dżihad w Gruzji, 21 September 2010, www.psz. pltekst-33917/Liberalna-demokracja-i-prawoslawny-dzihad-w-Gruzji (access: 20 June 2015).

127 Премьер-министр Грузии: Вся наша история зиждется на христянской вере, Православие. $\mathrm{Ru}, 15$ December 2014, http://www.pravoslavie.ru/news/70715.htm (access: 16 December 2015).

128 Public Attitudes in Georgia: Results of an April 2014 Survey, https://www.ndi.org/files/Georgia-April14-Survey-Political-English.pdf (access: 20 June 2015). 
thirty-four times, but not all of them have received a good theological education. It is these clerics who are more likely to promote and support ultraconservative movements within the Georgian Church. Taking into account the influence of the Catholicos and the Georgian Patriarchate on the formation of public opinion, the situation described above can have far-reaching consequences for internal and foreign policy of Georgia. ${ }^{129}$

Despite reluctance to accept other faiths, the Georgian Church has favourably referred to the government decree issued on 7 February 2014 on the establishment of an agency which is to pay compensation for damages suffered in Georgia by religious organisations during the Soviet regime. ${ }^{130}$ Compensation and subsidies from the state budget are to be received by, apart from the Georgian Church, four other religious communities: Muslim, Armenian, Catholic and Jewish. The Prime Minister Irakli Garibashvili, who in this way wants to settle relations between the state and religious associations, said that the funds would be allocated in proportion to the number of the believers. ${ }^{131}$

The act of the Holy Synod of the Orthodox Church of Georgia from 4 June 2014 serves as a guarantee of its interests and is a complement to the constitutional agreement. It stipulates e.g. the appointment of a bilateral committee tasked with describing church monuments and religious objects kept in store of Georgian museums, and to present a report on their condition. The Georgian Church, working closely with the Ministry of Culture, is to look after the ownership and safety of the cultural heritage of the Church, both in Georgia and abroad. All Georgian parishes operating outside the country will establish Georgian spiritual centres and Sunday schools. The Patriarchate together with the Theological Academy is to be responsible for the preparation of curricula and textbooks for the Sunday schools. In order to recover its administrative structures and staff parishes in Abkhazia and South Ossetia, the Church has decided to request assistance from international organizations and government agencies, working as groups for a Russian-Georgian dialogue. The Holy Synod has voiced its opposition to the anti-discrimination law, unacceptable to the Georgian Church, and expressed the hope that in the near future this law would be changed. ${ }^{132}$

According to the data in the International Religious Freedom Report for 2013, there are still many cases in which this law is violated in Georgia. Only the

129 М. Корсо, Грузия: Православная иерковь может превратиться в очаг нетерпимости?, 26 June 2013, Eurasianet.org, https://russian.eurasianet.org/node/60169 (access: 20 June 2015).

130 The decision was announced by the authorities already on 27 January 2014, bsfsnom $30 \mathrm{mml}$

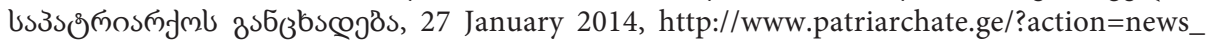
show\&mode=news\&id=789 (access: 22 June 2015).

131 “Gruzja: władze zamierzają finansować Kościół katolicki”, Niedziela, 27 January 2014, http:// www.niedziela.pl/artykul/7723/Gruzja-wladze-zamierzaja-finansowac (access: 22 June 2015).

132 Обнародовано постановление Священного Синода Грузинской Православной Церкви, 6 June 2014, Образование и Православие, http://www.orthedu.ru/hppc/news-hppc/10448-14.html (access: 25 June 2015). 
Georgian Church is financed from the state budget, and it is also exempt from most taxes. Religious education in school, overseen by the Georgian Church, cannot be controlled by school authorities. The Georgian Church receives preferential treatment from the government in the financing of temple restoration. Other churches, including the Roman Catholic Church and the Armenian Apostolic Church, have complained that disputes about ownership have not been resolved on the basis of a transparent legal process, but on a case-by-case basis, clearly favouring the claims of the Georgian Church. Unsolved disputes regarding the belonging of various religious buildings to specific Churches, and dragging the situation out are conducive to the rise of conflicts between individual faith groups, and cause the contentious historic buildings to fall into disrepair. Representatives of other religions have complained about the inability to recover some of their buildings from the government, as they have been registered as objects of cultural heritage - such talks have been conducted by the government, with the support of the Georgian Church, with the Jewish community in Tbilisi, Gori, and Batumi. The Ombudsman continues to receive numerous complaints from Jehovah's Witnesses (33 in 2013), as well as from Muslims, followers of the Armenian Apostolic Church, the Pentecostal Church, Adventists, and Evangelicals. The Ombudsman has also raised the issue of promoting the principles proclaimed by the Georgian Church by teachers, and using religious emblems in lessons. Members of religious minorities are afraid to report abuse committed in schools to the appropriate Ministry of Education department, fearing that teachers would retaliate on children, and feeling that their actions would not be effective. Another example of not respecting religious freedom in Georgian schools is setting exam dates on Saturdays, which is at odds with the religious principles of Jews and Adventists. The report also lists specific examples of abuse faced by representatives of the Georgian society due to their affiliation with other religious associations. Ilia II commented on the reports of not respecting religious freedom in Georgia with a statement, widely quoted in the media, that these days "the majority is often more oppressed" than minorities. ${ }^{133}$

As if attempting to compensate for all of this to other religions and Churches, the government participates in a variety of celebrations they organise. The Prime Minister B. Ivanishvili greeted the Catholics at Easter and ate iftar with Muslim leaders during Ramadan. The National Library organised celebrations of the International Holocaust Remembrance Day. The Ministry of Defence has started educating Georgian armed forces taking part in international operations about religious sensitivity issues - the battalion involved in the Afghanistan mission has been taught history, tradition and principles of Islam. By the end of 2013, the Government registered 22 minority religious groups as public law entities,

133 Georgia 2013 International Religious Freedom Report, Department of State USA, 28 July 2014, www.state.gov/documents/organization/222429.pdf (access: 15 July 2015). 
including three Catholic Church groups, four Muslim ones, one Lutheran, one Yazidi, and two Jewish groups. ${ }^{134}$

The Georgian Church has also shown pro-peace activities, in an effort to alleviate the conflict between Georgia and Russia. Since the dissolution of the USSR, the Georgian Church and the Russian Orthodox Church have made efforts for good cooperation. They offered each other support in the time of internal schisms experienced by both Churches in the 1990s. They also consistently boycott schismatic communities. Both the Georgian Church and the Russian Orthodox Church are very distrustful towards the Vatican and the ecumenical trend. On 20 May 1997 the Georgian Church withdrew from the World Council of Churches and the Conference of European Churches, whose member it had been since 1962. ${ }^{135}$ Representatives of the Georgian Patriarchate actively join celebrations organised by the Moscow Patriarchate. In August 2013, Ilia II took part in the $1025^{\text {th }}$ anniversary of the baptism of Rus'. In February 2014, a Georgian Patriarchate delegation participated in celebrations taking place in the Donskoy Monastery in Moscow, where underground crypts are the place of burial of Georgian clerics, nobles, and members of the royal dynasty of Imereti. The main purpose of the visit was to collect an icon of Saint Sergei, created at the School of Icon Painting at the Moscow Theological Academy. The icon is to be placed in the Georgian Saint Gregory monastery in Alaverdi, in the province of Lori in northern Armenia. ${ }^{136}$

Relations between the Georgian Church and the Russian Orthodox Church are complicated by the issue of Abkhazia and South Ossetia. In Abkhazia, parallel to the political conflict, there has been an ongoing conflict between Abkhazian parishes which wanted to become independent from Georgia and move to the jurisdiction of the Moscow Patriarchate. The Georgian Church considers the Abkhazian eparchy (or diocese) as part of its canonical area. ${ }^{137}$ The Russian Orthodox Church has concluded that they form a part of the Georgian Church's territory. However, it has not prevented it from exercising informal care over the Abkhazian parishes. On behalf of the Moscow Patriarchate, the Orthodox Abkhazians are overseen by bishop Panteleimon Maykovsky. A commotion in the Georgian Church was caused on 9 January 2007 by the presentation of an Abkhazian translation of the New Testament in Moscow, and a decision to give a copy of the translation to Orthodox parishes in Sukhumi. The Georgian Church accuses the Russian Orthodox Church of training Abkhazian clergy in the Moscow Theological Seminary, supplying them with religious literature and liturgical objects, and carrying out activities contrary to

134 Ibid.

135 Król-Mazur, Polityczne aspekty, p. 299.

${ }_{136}$ Московский Патриархат принимает делегаиию Грузинской Православной Церкви, 13 February 2014, Образование и Православие, http://www.orthedu.ru/newOбразование и Православиеs/9388-14.html (access: 25 June 2015).

137 Before taking office of the Catholicos - Patriarch of All Georgia, Ilia II was the archbishop of Sukhumi-Abkhazia. 
the canon law by the clergymen of the Moscow Patriarchate. Also, the presence of the Bishop of Stavropol and Vladikavkaz, Feofan, caused outrage at the swearing-in ceremony of the president of South Ossetia, Eduard Kokoity, not recognised by the Georgian authorities. The Georgian Church did not accept the decision of the Abkhazian Orthodox Church about its independence from Georgia, announced in September 2009. ${ }^{138}$ At the same time, the Moscow Patriarchate declared its respect for the existing borders of the jurisdiction of the Georgian Church. The Patriarch of Constantinople took a similar stand. ${ }^{139}$ However, the local church in Abkhazia takes various efforts to remove all of the past associations with the Georgian Church, e.g. by modifying architecture to eliminate all Georgian characteristics. ${ }^{140}$

A rebellious community in South Ossetia, centred around Father Alexander (Georgy Pukhaiev), has called to join the Russian Orthodox Church. Since the Russian Orthodox Church refused, at first a decision was made to pass under the jurisdiction of the Russian Orthodox Church Outside Russia, then to create the Diocese of South Ossetia - Alania. The Moscow Patriarchate also in this case did not accept the decision to become independent from Georgia. ${ }^{41}$

However, it should be noted that the cause of the civil war in Georgia (1992-1994) was the deeply rooted nationalism among Georgians, Abkhazians and Ossetians, and religion became one of the important components of identity for the feuding nations.

The events of August 2008 became the test of the relationship between the Georgian Church and the Russian Orthodox Church. Catholicos Ilia II deplored the conflict between the two Orthodox countries, ${ }^{142}$ but emphasised that it did not have a religious dimension, but that its causes were global and political, and that Georgia had become the battlefield for world powers and forces. The statement of the Ossetian bishop George was a reference to the political choices of Georgia (accession to NATO, training of Georgian soldiers by the Turkish military), as in a letter to the Catholicos he lamented the fact that experiences of joint fight against "Muslim invaders" had been forgotten, and that "Georgia now took Islamic Turkey for an ally [...] 'learning from their instructors how to kill brothers

138 Curanović, Rosyjsko-kaukaskie sąsiedztwo, pp. 389-390; Król-Mazur, Polityczne aspekty, p. 300 .

139 G. Hewitt, Discordant Neighbours: A Reassessment of the Georgian-Abkhazian and Georgian-South Ossetian Conflicts, Leiden, 2013, pp. 284-285; Moscow Patriarchate shall not encourage the separation of the Abkhaz Diocese from Georgian Church, 16 September 2009, http://www.interfax-religion.com/?act=news\&div=6445 (access: 22 June 2015).

140 Georgia 2013 International Religious Freedom Report, Department of State USA, 28 July 2014, p. 8, www.state.gov/documents/organization/222429.pdf (access: 15 July 2015).

141 Król-Mazur, Polityczne aspekty, p. 300.

${ }^{142}$ Interestingly, there have been statements in the Polish media showing solidarity with Georgia due to the fact that it is "a Christian country", but overlooking the fact that the war was conducted between two Christian nations, M. Domagała, Percepcja konfliktu kaukaskiego w polskich mediach w 2008 r., Warszawa, 2014, pp. 371-372. 
in faith"'. ${ }^{143}$ Ilia II not only urged everyone to "stop the armed conflict", but also reminded both nations that they were bound by a centuries-old friendship, family ties, and Christian faith. ${ }^{144}$

The traditional close ties with the Russian Orthodox Church facilitated the Georgian Church's involvement in mediation between Georgia and Russia, which played a crucial role during the Russo-Georgian War. The Catholicos visited the Russian war zone and personally negotiated with the Russian military command on the issue of taking the bodies of Georgian soldiers. ${ }^{145}$

The Georgian Church tried to silence the growing prejudices, maintaining, especially after the war of 2008 , the officially non-existent diplomatic relations. The Catholicos intervened immediately after the start of the fighting, sending a letter to the Russian President Dmitry Medvedev and the Prime Minister Vladimir Putin. He conducted a telephone conversation with Metropolitan Kirill, the head of the Department for External Ecclesiastical Relations of the Moscow Patriarchate. Ilia II also asked the Russian President not to approve Duma's provision on the independence of Abkhazia and South Ossetia. ${ }^{146}$ Both patriarchates (Georgian and Russian) organised humanitarian aid for the inhabitants of the war-affected regions. ${ }^{147}$

Nevertheless, Ilia II always stresses that Abkhazia and South Ossetia, "are traditional Georgian lands". ${ }^{148}$ Therefore, he instantly reacted to the wishes sent by the Patriarch of Moscow, Kirill, to the people of South Ossetia on the twentieth anniversary of "independence". He issued a letter to the Patriarch, in which he wrote that the step was incomprehensible, as by it Kirill "recognises the separatist regime established by violence, against the law, on land which for centuries has been Georgian". He deplored Kirill's statement, noting that "the Church should not be influenced by politicians and political processes". He also expressed his belief that the Moscow Patriarchate would, as it had in the past, show concern for the canonical borders of the Georgian Orthodox Church. ${ }^{149}$

Ilia II enjoys respect in Moscow, of which the best proof was the award, presented to him on 21 January 2013, by the International Foundation for the

${ }^{143}$ Ibid., p. 368.

144 Ibid.

145 Патриарх Илия II: были братьями и останемся братьями, 10 August 2013, Образование и Православие, http://www.orthedu.ru/news/7667-patriarx-iliya-ii-byli-bratyami-i-ostanemsya-bratyami.html (access: 26 June 2015).

146 Król-Mazur, Polityczne aspekty, p. 301.

${ }^{147}$ J. Ćwiek-Karpowicz, "Cerkiew prawosławna w polityce zagranicznej Rosji", Biuletyn PISM, 9 August 2010, no. 110 (718), p. 2281, http://www.pism.pl/zalaczniki/Biuletyn_718_3.pdf. (access: 20 July 2015).

148 Eliasz II Patriarcha Gruzji, http://edu.gazeta.pl/edu/h/Eliasz+II+\%28patriarch+Gruzja\%29\#Dzia. C5.82alno.C5.9B.C4.87_w_Gruzji (access: 22 June 2015).

149 Rosyjsko-gruziński konflikt prawosławny, Radio Watykańskie, 27 September 2010, http://www. deon.pl/religia/kosciol-i-swiat/z-zycia-kosciola/art,3191,rosyjsko-gruzinski-konflikt-prawoslawny. html (access: 16 December 2015). 
Unity of Orthodox Christian Nations "for special merits in the work of strengthening the fraternal ties between the Orthodox nations and Churches". ${ }^{150}$ The Catholicos then met with the President Vladimir Putin, passing on greetings from the new Prime Minister B. Ivanishvili. ${ }^{151}$ Ilia II is one of the few representatives of Georgia who can easily travel from Georgia to the Russian Federation, and the only one who has officially met with the highest representatives of the Russian state, including Vladimir Putin, leading negotiations on the most important issues for the interests of Georgia. ${ }^{152}$ In interviews Ilia II emphasises that he loves Russia and its culture, and the period of study spent at the seminary in Russia allowed him to understand the Russian character. ${ }^{153}$

Some political scientists believe that the pro-Western course adopted by Georgian authorities, about which the Georgian Church is increasingly unhappy, has been the cause of strengthening the relationship between the local Church and the Patriarchate of Moscow. Kornely Kakachia believes that since the war of 2008 Russia has been trying milder methods of restoring its influence in Georgia - reminding it of their common history through the Orthodox Church and religion. ${ }^{154}$ For the Moscow Patriarchate it is important to regulate the situation in Abkhazia, where there has been further division (including young priests affiliated with the New Athos monastery wanting greater consideration for Abkhazia's own, Christian tradition and independence from Russian Orthodox Church). ${ }^{155}$

The Georgian authorities face problems due to some of the Catholicos' public statements in which he speaks about the international situation, especially if they relate to its closest neighbours. An example may be the words spoken to Azeri clergy who participated in the concert held on the eightieth birthday of the head of the Georgian Church: "Karabakh belongs and will belong to Azerbaijan". ${ }^{156}$ Officially, the Georgian government takes a neutral stance in the Nagorno-Karabakh conflict, stressing the need for a peaceful solution - this was also the position of the Prime Minister B. Ivanishvili, when in January 2013 he paid a visit to Armenia. ${ }^{157}$

Analysing the relationship between religion and politics in Georgia, we can see that national identity is based on self-identification with religion (we can see

150 Do Rosji przybywa Katolikos-Patriarcha Gruzji Eliasz II, 20 January 2013, http://polish.ruvr. ru/2013_01_21/Do_Rosji_przybywa_Katolikos_Patriarcha_Gruzji_Eliasz_II (access: 22 July 2015).

${ }^{151}$ K. Zasztowt, "Georgian Dream's Foreign Policies: An Attempt to Change the Paradigm?", The Polish Institute of International Affairs Policy Paper, 3(51) (2013), p. 4.

152 Патриарх Илия II: были братьями и останемся братьями, 10 August 2013.

153 Ibid.

154 Dyskryminacja ateistów w Gruzji. Wplywy Cerkwi w interesie Rosji, 21 July 2015, http://onet. tv/i/dowiedzsie/dyskryminacja-ateistow-w-gruzji-wplywy-cerkwi-w-interesie-rosji/3zdzlh (accessed 22 July 2015).

155 Curanović, Religie, Kościoły i konflikty, p. 219.

156 Katolikos Eliasz II: Abchazja i Osetia Południowa przynależa do Gruzji.

157 Wojtasiewicz, Polityka zagraniczna Republiki Gruzji, p. 142. 
it clearly on the example of non-Georgian communities, which have lived in Georgia for generations and speak the local language, but are treated as "foreign" because of their "non-Orthodox" and therefore "non-Georgian" faith), which unfortunately leads to negative consequences as the area of politics intentionally (or unintentionally) uses it to achieve its own goals. Religion is perceived as an important element of national tradition, and the return to tradition is a characteristic of most post-Soviet societies. For the ruling elite it is also beneficial because they can use the argument of tradition to fend off allegations about a lack of systemic reforms. ${ }^{158}$ Religion has been instrumentalised and used to achieve current political goals. At the same time, the Georgian Church "enters politics" engaging in activities closely linked to broadly understood politics. The political power manifests its far-reaching concern about religious matters, which encourages the Georgian Church to support such authorities. We can even venture to say that for some time there was a situation in Georgia in which politics served religion. We could say that the conduct of the Georgian Church confirms the thesis of Patrick Michel that "religion, contrary to its official mission of proclaiming the universal, is used primarily to express - and justify - the particular [...]. Instead of becoming a place to resolve tensions and conflicts, religion, by supporting and affirming the construction of nationalistic identity, becomes a place of exclusion of the other". ${ }^{159}$ In Georgia, the rivalry between the state and the Georgian Church in the use of religion for political and ideological purposes to mobilise the society is clearly visible. ${ }^{160}$ We could say that there is a temptation in this country to transform politics into a religion, and religion into politics. The clergy are involved (either directly or indirectly) in ethno-religious and social conflicts taking place in Georgia. However, their involvement varies depending on the region and the size of religious centres. A positive aspect of these activities is the effort to mitigate conflict, ${ }^{161}$ while negative aspects are the support of some clerics for nationalist groups, giving special blessing to those involved in the conflict, taking over temples from followers of other religions, and building temples on ethno-religious borderlands. Of particular importance here is the voice of the head of the Georgian Church - the Catholicos, who enjoys the greatest trust of society and so has the highest potential to influence the way the situation in Georgia develops. It also

158 This problem has been generally analysed by A. Curanović, "Kontrolowana 'zemsta Boga': znaki szczególne poradzieckiego systemu wyznaniowego", in: Religia i polityka na obszarze Europy Wschodniej, Kaukazu i Azji Centralnej, ed. T. Stępniewski, Lublin-Warszawa, 2013, pp. 35-48.

159 P. Michel, Politics and religion in Eastern Europe, Cambridge, 1991, pp. 84-85.

160 Król-Mazur, Polityczne aspekty, pp. 281-303; P. Dundua, "Religious Factors in Georgian Politics (the 2008 General Elections)", Central Asia and the Caucasus, 1 (2010), pp. 173-180; B. Chedia, "The Georgian Orthodox Church in Current Georgian policy", Central Asia and the Caucasus, 4-5(58-59) (2009), pp. 169-175.

161 The involvement of clerics in overcoming ethnic and ethno-religious conflicts referred to as faith-based diplomacy also takes the form of institutional capacity at both national level (e.g. various councils, comprising representatives of different Churches), and internationally. 
seems appropriate to refer to Georgia René Girard's reflection that religion offers peace, but its roots are in violence. ${ }^{162}$ Religion in Georgia inspires nationalist entities and supports nationalism.

Translated by Damian Jasiński

\section{The role of the Georgian Apostolic Autocephalous Orthodox Church in conflicts in the South Caucasus Abstract}

The dissertation focuses on mutual ties and relations between the Church and the authorities and politics in Georgia. The national identity of Georgians is strongly connected with Christianity and separate ecclesiastical structures. A long tradition of autocephaly and differences resulting from autonomous development created a specific feeling of attachment to the Church, which Georgians expressed in the opposition to subordinate their Church to Russian Orthodox Church, the Russian Empire, and the Soviet power. The position of Georgian Autocephalous Orthodox Church in the country's life after the fall of the communism was shaped by the political situation of that period. The role of the national church was strongly emphasised and freedom regaining Georgians combined national slogans with their religious orientation. For a long time, the Georgian Church was the only one allowed to function in Georgia. The authorities, in need of the Church's support, decided to give it an exceptional role in the state (Art. 9 of 1995 Constitution and the "Constitution Agreement" executed and ratified in October 2002 by the parliament and the Holy Synod). These and other provisions included in the legal acts resulted in a tremendous preference of the Georgian Church which leads to the spreading of religious extremism in the country, initially tolerated by the authorities. However, with the demands to introduce political reforms aimed at bringing Georgia closer to the model of Western countries and the country's aspiration to join the European Union, the authorities were compelled to take steps and decisions which were contrary to the standpoint and activity of the Georgian Church. This, however, for long time enjoying incredible social trust, managed to maintain its position, among the others due to the ability to skilfully balance between the expectations and needs of the authorities and the accomplishment of its own goals. The Georgian Church is considered one of the most important actors in the Georgian public life and its influence on politics is considerable. It plays a significant role both in exacerbating ethnic, religious, and social conflicts in Georgia which translates into the relations of the country with its neighbours and the mitigation of emerging problems (after the Georgian-Ossetian-Russian war, the Georgian Church is the sole representative of the State in relations with the Russian Federation.

\section{Роль Грузинской Апостольской Автокефальной Православной Церкви в конфликтах на Южном Кавказе Аннотация}

Задачей статьи является приблизить вопросы, связанные с присутствием християнства на территории Грузии и показать насколько большую роль играет Грузинская Апостольская Автокефальная Православная Церковь в истории грузинского народа. Национальная

162 R. Girard, Violence and the Sacred, transl. M. and J. Pleciński, Poznań, 1993. 
идентичность грузин сильно связана с християнством и отдельными церковными структурами, что существенно влияет на отношения с негрузинскими общинами (на Южном Кавказе - Грузия - страна с самым большим процентом этнических меньшинств), много поколений живущими в Грузии и владеющими местным языком, но к которым относятся как к «чужим» из-за «негрузинской» конфессии

Новые власти (после обретения Грузией независимости в 1991 г.) обеспечили исключительную роль в государстве Грузинской Апостольской Автокефальной Православной Церкви посредством соответствующего законодательства. Это способствовало обострению отношений с национальными и конфессиональными меньшинствами, а также, в большой степени, усилению социальной напряженности и отразилось также на отношениях Грузии с ближайшими соседями. Именно эти аспекты автор подробно рассматривает в представленном тексте и показывает, как в результате специфических отношений, которые образовались в Грузии между церковью и государством, религия была подвержена инструментализации и использована для достижения текущих политических целей. В заключение статьи утверждается, что религия в Грузии вдохновляет националистические субъекты и поддерживает национализм.

\section{Bibliography}

\section{Sources}

Porozumienie Konstytucyjne między Państwem Gruzińskim i Gruzińskim Apostolskim Autokefalicznym Kościołem Prawosławnym z 14 X 2002, in: Badania wschodnie. Polityka wewnętrzna i międzynarodowa, ed. W. Baluk, Z.J. Winnicki, Wrocław, 2008.

The Constitution of the Republic of Georgia, Parliament of Georgia, http:// www.parliament. ge/files/68_1944_951190_CONSTIT_27_12.06.pdf

\section{Literature}

Baramidze R., "Islam in Adjara - Comparative Analysis of Two Communities in Adjara", in: Changing identities: Armenia, Azerbaijan, Georgia. Collection of Selected Works, ed. V. Voronkov, Tbilisi, 2011.

Chmielowski T.T., "Kościół Prawosławny w Gruzji w latach zaboru rosyjskiego i władzy sowieckiej (XIX-XX w.)", Archiwa, Biblioteki i Muzea Kościelne, 1998, no. 70.

Corm G., Religia i polityka w XXI wieku, transl. E. Cylwik, Warszawa, 2007.

Curanović A., "Kontrolowana 'zemsta Boga': znaki szczególne poradzieckiego systemu wyznaniowego", in: Religia i polityka na obszarze Europy Wschodniej, Kaukazu i Azji Centralnej, ed. T. Stępniewski, Lublin-Warszawa, 2013.

Curanović A., "Religie, Kościoły i konflikty międzywyznaniowe w regionie Kaukazu", in: Armenia, Azerbejdżan, Gruzja. Przeszłość i teraźniejszość, ed. M. Korzeniowski, D. Tarasiuk, K. Latawiec, Lublin, 2013.

Curanović A., "Rosyjsko-kaukaskie sąsiedztwo w kontekście stosunków międzywyznaniowych", in: Kaukaz w stosunkach międzynarodowych. Przeszłość, teraźniejszość, przyszłość, ed. P. Olszewski, K. Borkowski, Piotrków Trybunalski, 2008.

Chedia B., "The Georgian Orthodox Church in Current Georgian policy", Central Asia and the Caucasus, 4-5 (58-59) (2009).

Domagała M., Percepcja konfliktu kaukaskiego w polskich mediach w 2008 r., Warszawa, 2014. 
Dundua S., "Religious Factors in Georgian Politics (the 2008 General Elections)", Central Asia and the Caucasus, 1 (2010).

Fox J., Sandler S., Bringing Religion into International Relations, New York, 2004.

Furier A., Droga Gruzji do niepodległości, Poznań, 2009.

Furier A., "Znaczenie relacji między Kościołem a władzami państwowymi dla kształtowania się państwa i narodu gruzińskiego", in: Etniczność a religia, ed. A. Posern-Zieliński, Poznań, 2003.

Girard R., Sacrum i przemoc, transl. M. and J. Pleciński, Poznań, 1993.

Gruzja między Wschodem a Zachodem, ed. K. Masiuk et al., Kraków-Warszawa, 2012.

Hewitt G., Discordant Neighbours: A Reassessment of the Georgian-Abkhazian and Georgian-South Ossetian Conflicts, Leiden, 2013.

Kakachia K., "Is Georgia’s Orthodox Church an Obstacle to European Values?", PONARS Eurasia Policy Memo, no. 322, June 2014, http://www.ponarseurasia.com/sites/default/files/ policy-memos-pdf/Pepm_332_Kakachia\%20_June\%202014.pdf (access: 20 May 2015).

Komoszyńska I., "Niektóre aspekty współczesnych antagonizmów gruzińsko-ormiańskich", in: Dylematy kaukaskie. Problemy narodowościowe i migracyjne, ed. M. Ząbek, Warszawa, 2010.

Kończak L., "Religia i konflikty religijne w niepodległej Gruzji", in: Konflikty na obszarze byłego ZSRR, ed. P. Adamczewski, Poznań, 2009.

Król-Mazur R., "Polityczne aspekty działalności Prawosławnego Autokefalicznego Apostolskiego Kościoła Gruzińskiego po 1991 r.", in: Na wschód od linii Curzona. Księga Jubileuszowa dedykowana profesorowi Mieczysławowi Smoleniowi, ed. R. Król-Mazur, M. Lubina, Kraków, 2014.

Kuca G., Grzybowski M., System konstytucyjny Gruzji, Warszawa, 2012.

Laboa J.M., "Monastycyzm gruziński”, in: Mnisi Wschodu i Zachodu. Historia monastycyzmu chrześcijańskiego, ed. J.M. Laboa, Warszawa, 2009.

Legucka A., Geopolityczne uwarunkowania i konsekwencje konfliktów zbrojnych na obszarze poradzieckim, Warszawa, 2013.

Leszczenko L., Instytucja ombudsmana w państwach poradzieckich. Geneza - status prawny rozwój, Warszawa, 2011.

Marczewska-Rytko M., Religia i polityka w globalizującym się świecie, Lublin, 2010.

Mariański J., “Globalizacja i Kościoły - sprzymierzeńcy czy konkurenci”, in: Religia i religijność w warunkach globalizacji, ed. M. Libiszowska-Żółtkowska, Kraków, 2007.

Marjanli M., Armenians. Russia. The Caucasus, Dubai, 2011.

Marsagiszwili M., "Działalność Departamentu Policji Patrolowej Gruzji. Prawa Człowieka”, in: Polsko-gruzińska wymiana doświadczeń $w$ zakresie podejmowania czynności służbowych przez funkcjonariuszy policji w aspekcie praw i wolności człowieka, ed. I. Nowicka, T. Mosio, Szczytno, 2008.

Materski W., Gruzja, Warszawa, 2010.

Matiunin S., "Konflikty religijne na terenie byłego ZSRR", in: Religie i kościoły w społeczeństwach postkomunistycznych, ed. I. Borowik, A. Szyjewski, Kraków, 1993.

McGuire M.B., Religia w kontekście społecznym, transl. S. Burdziej, Kraków, 2012.

Modebadze V., "Historical Background of Meskhetian Turks' Problem and Major Obstacles to the Repatriation Process", IBSU Scientific Journal, 3(1) (2009).

Nieczuja-Ostrowski P., "Religia w polityce w państwach Kaukazu Południowego", in: Religia i polityka na obszarze Europy Wschodniej, Kaukazu i Azji Centralnej, ed. T. Stępniewski, Lublin-Warszawa, 2013.

Parzymies D., Życie codzienne w Tbilisi 1999-2003, Warszawa, 2004.

Pataraia T., "Rozwój polityki migracyjnej w Gruzji”, in: Polityka migracyjna Gruzji: wnioski $z$ polskich doświadczeń, ed. P. Kaźmierkiewicz, T. Pataraia, Warszawa, 2011. 
Peradze G., Kościół Gruziński pod bolszewizmem”, in: id., Dzieła zebrane, vol. 2, ed. H. Paprocki, Warszawa, 2011.

Peradze G., “Problemy historii początków Kościoła Gruzińskiego”, in: id., Dzieła zebrane, vol. 2, ed. H. Paprocki, Warszawa, 2011.

Prześlakiewicz P., "Pamięć polskości w południowej Gruzji”, in: Etnos przebudzony, ed. L. Mróz, Warszawa, 2004.

Rtskhiladze G., "Religion and Conflict Potential in Georgia", Central Asia and the Caucasus, 3 (39) (2005).

Sabanadze N., Globalization and Nationalism: the Cases of Georgia and the Basque Country, Budapest-New York, 2010, http://books.openedition.org/ceup/573 (access: 1 July 2015).

Suny R.G., The Making of Georgian Nation, Bloomington, 1994.

Szabaciuk A., "Między konfliktem a pokojem. Polityka etniczna i wyznaniowa Gruzji w latach 1991-2012", Wschodnioznawstwo, 2012.

Szyszlak T.J., "Próby teoretycznego ujęcia postradzieckich konfliktów religijnych", in: Religia i polityka na obszarze Europy Wschodniej, Kaukazu i Azji Centralnej, ed. T. Stępniewski, Lublin-Warszawa, 2013.

Szyszlak T.J., "Stosunki państwa z Apostolskim Autokefalicznym Kościołem Prawosławnym we współczesnej Gruzji”, in: Badania wschodnie. Polityka wewnętrzna i międzynarodowa, ed. W. Baluk, Z.J. Winnicki, Wrocław, 2008.

Szyszlak T.J., "Wolność religijna w konstytucjach i ustawach wyznaniowych państw postradzieckich", Studia z Prawa Wyznaniowego, 10 (2007).

The Political Landscape of Georgia. Political Parties: Achievements, Challenges and Prospects, eds. G. Nodia, Á. Pinto Scholtbach, Delft, 2006.

Trier T., Tarkhan-Mouravi G., Kilimnik F., Meskhetian: Homeward Bound..., Tbilisi, 2011.

Wojtasiewicz W., "Polityka zagraniczna Republiki Gruzji pod rządami premiera Bidziny Iwaniszwilego - kontynuacja czy zmiana?", in: Prawo i polityka na wschód od Europy, ed. J. Marszałek-Kawa, P. Wawrzyński, Toruń, 2014.

Zadura D., "Chrześcijaństwo i Kościół narodowy w historii Gruzji - od źródeł do okresu sowieckiego", Pro Georgia. Journal of Kartvelological Studies, 19 (2009).

Zadura D., "Naród w tygrysiej skórze. Tożsamość narodowa Gruzinów w dobie 'rewolucji róż"', in: Dylematy kaukaskie. Problemy narodowościowe i migracyjne, ed. M. Ząbek, Warszawa, 2010.

Zajączkowski W., Rosja i narody. Ósmy kontynent - szkic $z$ dziejów Eurazji, Warszawa, 2009.

Zasztow K., "Georgia Dream's Foreign Policie: An Attempt to Change the Paradigm?", The Polish Institute of International Affairs Policy Paper, 3(51) (2013).

Zenderowski R., Religia a tożsamość narodowa i nacjonalizm w Europie Środkowo-Wschodniej. Między etnicyzacja religii a sakralizacją etnosu (narodu), Wrocław, 2011.

Гаджиев К.С., Кавказский узел в геополитических приоритетах России, Москва, 2010.

Рамишвили В., “Армяно-Грузинский спор: Джавахети или Джавахк?”, Кавказ \& Глобализачия. Журнал социально-политических и экономических исследований, 5 (2007), http://www.ca-c.org/c-g/2007/journal_rus/c-g-4/02.shtml (access: 1 July 2015).

Силантьев Р., “Религиозный фактор во внешнеполитических конфликтах на Кавказе”, in: Религия и конфликт, ред. А. Малашенко, С. Филатов, Москва, 2007.

Токарев А., Влияние государственности на эволючию политических режимов Грузии и Украины в 1991-2014 годах, Москва, 2015.

\section{Analyses and reports}

Cerkiew protestuje przeciwko nowemu prawu, http://www.kaukaz.info/cerkiew-protestuje-przeciwko-nowemu-prawu.html (access: 29 June 2014). 
Chanadiri A., Gruzini. Zagubieni Europejczycy, 14 December 2013, http://zw.lt/opinie/gruzini-zagubieni-europejczyzy/ (access: 9 July 2015).

Ćwiek-Karpowicz J., "Cerkiew prawosławna w polityce zagranicznej Rosji”, Biuletyn PISM, 9 August 2010, no. 110 (718), p. 2281, http://www.pism.pl/zalaczniki/Biuletyn_718_3.pdf. (access: 20 July 2015).

Do Rosji przybywa Katolikos-Patriarcha Gruzji Eliasz II, 20 January 2013, http://polish.ruvr. ru/2013_01_21/Do_Rosji_przybywa_Katolikos_Patriarcha_Gruzji_Eliasz_II (access: 22 July 2015).

Dyskryminacja ateistów w Gruzji. Wpływy Cerkwi w interesie Rosji, 21 July 2015, http://onet. tv/i/dowiedzsie/dyskryminacja-ateistow-w-gruzji-wplywy-cerkwi-w-interesie-rosji/3zdzlh (access: 22 July 2015).

Dzieduszycka-Manikowska A., "Dramat kościoła na Kaukazie”, PCh24.pl, 4 August 2013, http:// www.pch24.pl/Mobile/Informacje/informacja/id/16759 (access: 12 August 2015).

Eliasz II Patriarcha Gruzji, http://edu.gazeta.pl/edu/h/Eliasz+II+\%28patriarch+Gruzja\%29\#Dzia.C5.82alno.C5.9B.C4.87_w_Gruzji (access: 22 June 2015).

Falkowski M., Gruzja: kryzys polityczny i rosyjskie zagrożenie, Analizy Ośrodka Studiów Wschodnich, http://www.osw.waw.pl/pl/publikacje/analizy/2014-11-19/gruzja-kryzys-polityczny-i-rosyjskie-zagrozenie (access: 10 June 2015).

Georgia 2013. International Religious Freedom Report, Department of State, USA, 28 July 2014, www.state.gov/documents/organization/222429.pdf (access: 15 July 2015).

“Gruzin nie może być katolikiem”, Niedziela, 11 June 2008, www.niedziela.pl/wiad. php? $=200806 \& \mathrm{idw}=149$.

Gruzińska Cerkiew krytykuje nowe przepisy, http://wiadomosci.wp.pl/kat,1356,title,Gruzinska-Cerkiew-krytykuje-nowe-przepisy,wid,13573623, wiadomosc.html?ticaid=112548 (access: 20 July 2015).

“Gruzja: władze zamierzają finansować Kościół katolicki”, Niedziela, 27 January 2014, http:// www.niedziela.pl/artykul/7723/Gruzja-wladze-zamierzaja-finansowac (access: 22 June 2015).

Human Rights World Report 2014: Georgia, http://www.hrw.org/world-report/2014/country-chapters/georgia.

Matusiak M., "Wzrost nastrojów konserwatywno-nacjonalistycznych?", Ośrodek Studiów Wschodnich, 4 September 2013: http://www.osw.waw.pl/publikacje/analizy/2013_09_04/ gruzja-wzrost-nastrojow-konserwatywno-nacjonalistycznych (access: 4 June 2015).

Moscow Patriarchate shall not encourage the separation of the Abkhaz Diocese from Georgian Church, 16 September 2009, http://www.interfax-religion.com/?act=news\&div=6445 (access: 22 June 2015).

Ormianie w Gruzji, http://www.fundacjaormiańska.pl/ormianie-w-gruzji/ (access: 20 July 2015).

Patriarch Ilia II asking Turkish authorities to resume services at Georgian churches, Tbilisi, 13 September 2014, http://www.pravoslavie.ru/english/73691.htm (access: 20 June 2015).

Public Attitudes in Georgia: Results of an April 2014 Survey, http://www.ndi.org/files/Georgia-April14-Survey-Political-English.pdf (access: 20 June 2015).

Rada Europy o problemach mniejszości etnicznych i religijnych w Gruzji, Ośrodek Studiów Wschodnich, 12 October 2009, http://www.osw.waw.pl/pl//publikacje/tydzień-na-wschodzie/2009-10-12/rada-europy-o-problemach-mniejszosci-etnicznych-i-religijnych-w-Gruzji (access: 13.04.2015).

Szef watykańskiej dyplomacji oburzony postawa Gruzji, Katolicka Agencja Informacyjna (KAI), 21 September 2003, http://ekai.pl/wydarzenia/x5651/szef-watykanskiej-dyplomacji-oburzony-postawa-gruzji (access: 25 June 2015).

Tauber M., Geopolityka, sytuacja wewnętrzna w Gruzji, a stanowisko Gruzińskiej Cerkwi Prawosławnej, 22 April 2013, www.forum-ekonomiczne.pl/article/geopolityka-sytuacja- 
wewnętrzna-w-gruzji-a-stanowisko-gruzinskiej-cerkwi-prawoslawnej/\# (access: 12 January 2015).

The Georgian Authorities should not water down the country's first anti-discrimination bill, Amnesty International Public Statement, 24 April 2014, https://www.amnesty.org/en/documents/eur56/001/2014/en/ (access: 20 May 2015).

Rosyjsko-gruziński konflikt prawosławny, Radio Watykańskie, 27 September 2010, http://www. deon.pl/religia/kosciol-i-swiat/z-zycia-kosciola/art,3191,rosyjsko-gruzinski-konflikt-prawoslawny.html (access: 16 May 2015).

Wojtasiewicz W., "Wojna religijna" i afera szpiegowska w Gruzji", Nowa Europa Wschodnia (NEW), 18 July 2011, www.new.org.pl/2011-07-18,wojna_religijna_i_afera_szpiegowska_w_ gruzji.html (access: 20 July 2014).

Wojtasiewicz W., "Wybory za pasem", Nowa Europa Wschodnia (NEW), 4 April 2013, www. new.org.pl/2013-04-04,wybory_za_pasem.html (access: 5 June 2015).

Zadura D., Liberalna demokracja i prawosławny dżihad $w$ Gruzji, 21 September 2010, www. psz.pltekst-33917/Liberalna-demokracja-i-prawoslawny-dzihad-w-Gruzji (access: 20 June 2015).

Zadura D., Ormiańskie świątynie w Tbilisi, http:// www.kaukaz.net/cgi-bin/blosxom.cgi/polish/ gruzja/gruzja_ormianskie_koscioly (access: 14 June 2015).

Abramian G., Армения: Имущественные споры способствуют эскалащии напряженности между иерквями Армении и Грузии, 11 August 2011, Eurasianet.org, http://russian.eurasianet.org/node/58814 (access: 20 June 2015).

"В населенном армянами Самцхе-Джавахети поднят вопрос об автономии в составе Грузии", REGNUM, Информационное агентство, 22 August 2008, http://www.regnum. ru/news/1043811.html\#ixzz29rSJzn8C (access: 27 August 2015).

“Государство и Церковь в Грузии будут вместе сохранять культурное наследие", Образованне и Православие, 20 July 2014, http://www.orthedu.ru/hppc/news-hppc/10797gosudarstvo-i-cerkov-v-gruzii-budut-vmeste-sohranyat.html (access: 20 May 2015).

Грузия ведет переговоры с Азербайджаном о передаче монастыря Удабно входяего в комплекс Давид Гареджи, Православие.Ru, 15 May 2012, http://www.pravoslavie.ru/ news/53516.htm (access: 16 June 2015).

Грузия вошла в десятку самых религиозных стран, Православие.Ru, 14 April 2015, http:// www.pravoslavie.ru/news/78649.htm (access: 15 May 2015).

Грузия профинансирует Грузинскую Православную Церковь в размере 25 миллионов лари, Православие.Ru, 8 October 2013, http://www.pravoslavie.ru/news/64750.htm (access: 16 May 2015).

Двали Г., “Грузия отделилась от церкви”, Коммерсанть, 7 July 2011.

Илия II попросил Иран не наказывать грузин, возвращающихся в Христианство, 21 August 2013, Образование и Православие, http://www.orthedu.ru/news/7731-iliya-ii-poprosil-iran-ne-nakazyvat-gruzin-vozvrashhayushhixsya-v-xristianstvo.html (access: 25 June 2015).

Комплекс Давид Гареджи является клтурным памятником Грузии -

Грузинский МИД, Православие.Ru, 16 May 2012, http://www.pravoslavie.ru/news/53559.htm (access: 16 June 2015).

Корсо М., Грузия: Православная церковь может превратиться в очаг нетерпимости?, 26 June 2013, Eurasianet.org, https://russian.eurasianet.org/node/60169 (access: 20 June 2015).

Корсо М., Грузия: Растёт дискриминация в отношении мусульман?, 7 September 2013, Eurasianet.org, http://russian.eurasianet.org/node/60279 (access: 20 June 2015).

Мальцев В., Илия II: “Не унижайте Церковь!” Масштабные протесты православных верующих заставили власти Грузии свернуть с европейского пути, http://www.religare.ru/2_87652.html (access: 26 June 2015). 
Московский Патриархат принимает делегацию Грузинской Православной Церкви, 13 February 2014, Образование и Православие, http://www.orthedu.ru/news/9388-14.html (access: 25 June 2015).

Обнародовано постановление Священного Синода Грузинской Православной Церкви, 6 June 2014, Образование и Православие, http://www.orthedu.ru/hppc/news-hppc/10448-14. html (access: 25 June 2015).

Патриархи Грузии: Продажа земли иностраииам ставит под удар сущетвование государста, Православие.Ru, 14 July 2014, http://www.pravoslavie.ru/news/71975.htm (access: 16 May 2015).

Патриарх Илия II: бьли братьями и останемся братьями, 10 August 2013, Образование и Православие, http://www.orthedu.ru/news/7667-patriarx-iliya-ii-byli-bratyami-i-ostanemsya-bratyami.html (access: 26 June 2015).

Премьер - министр Грузии: Вся наша история зиждется на христянской вере, Православие.Ru, 15 Мау 2014, http://www.pravoslavie.ru/news/70715.htm (access: 16 May 2015).

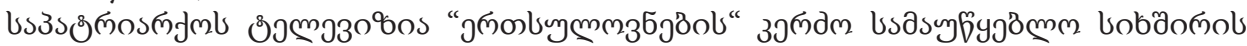
zsonozol zsдm, 14 June 2013, http://www.patriarchate.ge/?action=news_show\&mode$=$ news\&id=765 (access: 4 June 2015).

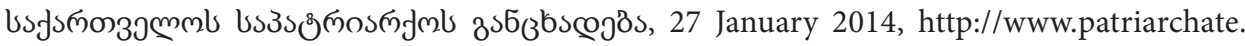
ge/?action=news_show\&mode=news\&id=789 (access: 22 June 2015).

Renata Król-Mazur, PhD, assistant professor in the Institute of Political Sciences and International Relations, Jagiellonian University; research interests: modern and recent history, particularly with regard to Poland, Ukraine, Russia, Armenia, the history of Caucasus, and issues related to national and ethnic minorities, military affairs and Polish political thought. She co-operates with the organisations of Armenian communities in Poland (reniakrol@poczta.onet.pl). 